\title{
Aerosol pH and chemical regimes of sulfate formation in aerosol water during winter haze in the North China Plain
}

\author{
Wei Tao ${ }^{1,2}$, Hang Su${ }^{1}$, Guangjie Zheng ${ }^{2}$, Jiandong Wang ${ }^{2}$, Chao Wei ${ }^{1}$, Lixia Liu ${ }^{2}$, Nan $\mathrm{Ma}^{3}$, Meng Li $^{1}$, Qiang Zhang ${ }^{4}$, \\ Ulrich Pöschl ${ }^{1}$, and Yafang Cheng ${ }^{2,1}$ \\ ${ }^{1}$ Multiphase Chemistry Department, Max Planck Institute for Chemistry, 55128 Mainz, Germany \\ ${ }^{2}$ Minerva Research Group, Max Planck Institute for Chemistry, 55128 Mainz, Germany \\ ${ }^{3}$ Institute for Environmental and Climate Research, Jinan University, Guangzhou 511443, China \\ ${ }^{4}$ Department of Earth System Science, Tsinghua University, Beijing 100084, China
}

Correspondence: Hang Su (h.su@mpic.de) and Yafang Cheng (yafang.cheng@mpic.de)

Received: 25 February 2020 - Discussion started: 6 April 2020

Revised: 7 August 2020 - Accepted: 26 August 2020 - Published: 17 October 2020

\begin{abstract}
Understanding the mechanism of haze formation is crucial for the development of deliberate pollution control strategies. Multiphase chemical reactions in aerosol water have been suggested as an important source of particulate sulfate during severe haze (Cheng et al., 2016; Wang et al., 2016). While the key role of aerosol water has been commonly accepted, the relative importance of different oxidation pathways in the aqueous phase is still under debate mainly due to questions about aerosol $\mathrm{pH}$. To investigate the spatiotemporal variability of aerosol $\mathrm{pH}$ and sulfate formation during winter in the North China Plain (NCP), we have developed a new aerosol water chemistry (AWAC) module for the WRF-Chem model (Weather Research and Forecasting model coupled with Chemistry). Using the WRF-ChemAWAC model, we performed a comprehensive survey of the atmospheric conditions characteristic for wintertime in the NCP focusing on January 2013. We find that aerosol pH exhibited a strong vertical gradient and distinct diurnal cycle which was closely associated with the spatiotemporal variation in the abundance of acidic and alkaline fine particle components and their gaseous counterparts. Over Beijing, the average aerosol $\mathrm{pH}$ at the surface layer was $\sim 5.4$ and remained nearly constant around $\sim 5$ up to $\sim 2 \mathrm{~km}$ above ground level; further aloft, the acidity rapidly increased to $\mathrm{pH} \sim 0$ at $\sim 3 \mathrm{~km}$. The pattern of aerosol acidity increasing with altitude persisted over the NCP, while the specific levels and gradients of $\mathrm{pH}$ varied between different regions. In the region north of $\sim 41^{\circ} \mathrm{N}$, the mean $\mathrm{pH}$ values at the surface level were typically greater than 6 , and the main pathway of
\end{abstract}

sulfate formation in aerosol water was S(IV) oxidation by ozone. South of $\sim 41^{\circ} \mathrm{N}$, the mean $\mathrm{pH}$ values at the surface level were typically in the range of 4.4 to 5.7 , and different chemical regimes and reaction pathways of sulfate formation prevailed in four different regions depending on reactant concentrations and atmospheric conditions. The $\mathrm{NO}_{2}$ reaction pathway prevailed in the megacity region of Beijing and the large area of Hebei Province to the south and west of Beijing, as well as part of Shandong Province. The transition metal ion (TMI) pathway dominated in the inland region to the west and the coastal regions to the east of Beijing, and the $\mathrm{H}_{2} \mathrm{O}_{2}$ pathway dominated in the region extending further south (Shandong and Henan provinces). In all of these regions, the $\mathrm{O}_{3}$ and TMI pathways in aerosol water, as well as the gas-particle partitioning of $\mathrm{H}_{2} \mathrm{SO}_{4}$ vapor, became more important with increasing altitude. Sensitivity tests show that the rapid production of sulfate in the NCP can be maintained over a wide range of aerosol acidity (e.g., $\mathrm{pH}=4.2-5.7$ ) with transitions from dominant TMI pathway regimes to dominant $\mathrm{NO}_{2} / \mathrm{O}_{3}$ pathway regimes.

\section{Introduction}

Persistent haze shrouding Beijing and its surrounding areas in the North China Plain during cold winters is one of the most urgent and challenging environmental problems in China (Sun et al., 2014; G. J. Zheng et al., 2015; Cheng et al., 2016; Su et al., 2020). The winter haze often has the follow- 
ing characteristic features, including stagnant meteorological conditions, high relative humidity, and high concentrations of $\mathrm{PM}_{2.5}$, as well as elevated contributions of secondary inorganics in $\mathrm{PM}_{2.5}$ (Zhang et al., 2014; Brimblecombe, 2012; G. J. Zheng et al., 2015; Sun et al., 2014). Although extremely sharp increases in $\mathrm{PM}_{2.5}$ concentration in Beijing (e.g., several hundred $\mu \mathrm{g} \mathrm{m}^{-3} \mathrm{~h}^{-1}$ ) have been attributed mainly to the transport processes rather than local chemical production, the large gap between modeled and observed $\mathrm{PM}_{2.5}$ reveals that there are still missing chemical formation pathways in the state-of-the-art atmospheric chemical transport models (G. J. Zheng et al., 2015; Cheng et al., 2016). Cheng et al. (2016) suggested and quantified that during severe haze, multiphase reactions in aerosol water can produce a remarkable amount of sulfate over a wide range of aerosol $\mathrm{pH}$ values which complements or even exceeds the contribution from gas-phase and cloud chemistry during the haze events. Laboratory studies of Wang et al. (2016) provide an experimental proof of the importance of the $\mathrm{NO}_{2}$ oxidation pathway in sulfate formation in aerosol water. However, depending on the aerosol $\mathrm{pH}$ and pollutant compositions, the major multiphase oxidation pathways may change from reactions of $\mathrm{NO}_{2}$ and $\mathrm{O}_{3}$ at $\mathrm{pH}$ greater than 4.5 to $\mathrm{O}_{2}$ (catalyzed by transition metal ion, TMI) and $\mathrm{H}_{2} \mathrm{O}_{2}$ at $\mathrm{pH}$ less than 4.5 (Cheng et al., 2016). Unlike the negative feedback between aerosol loadings and their photochemical production (Makar et al., 2015; Kong et al., 2015), the multiphase reactions induce a positive feedback mechanism, i.e., higher particle matter levels lead to more aerosol water, which accelerates sulfate production and further increases the aerosol concentration (G. J. Zheng et al., 2020; Su et al., 2020; Cheng et al., 2016).

Although the importance of reactions in aerosol water during severe haze has been widely accepted (Li et al., 2017a; Chen et al., 2016, 2019; G. J. Zheng et al., 2015; Cheng et al., 2016; Zhang et al., 2015; Wang et al., 2016; Shao et al., 2019; Xue et al., 2019; Gen et al., 2019; Wu et al., 2019), the exact formation pathway is still under debate. Besides the aforementioned reactions (i.e., reactions of $\mathrm{NO}_{2}, \mathrm{O}_{3}$, TMI, and $\mathrm{H}_{2} \mathrm{O}_{2}$ ), the heterogeneous production of hydroxymethanesulfonate (HMS) by $\mathrm{SO}_{2}$ and $\mathrm{HCHO}$ has also been proposed as contributing to the unexplained sulfate in models (Song et al., 2019; Moch et al., 2018). To a certain extent, this is not a surprise considering the strong dependence of the multiphase reaction rate on aerosol $\mathrm{pH}$ and pollutant compositions (including the most important oxidants for sulfate formation). Hourly predicted $\mathrm{pH}$ based on observations and thermodynamic model calculations showed a large variability from 2 to 8 in northern China (Shi et al., 2017; Ding et al., 2019). Previous observational and modeling studies also indicated that the temporal and spatial distribution of oxidants and catalysts, e.g., $\mathrm{O}_{3}$ (Dufour et al., 2010; $\mathrm{Xu}$ et al., 2008), $\mathrm{NO}_{2}$ (Zhang et al., 2012; Zhang et al., 2007), and TMI (Dong et al., 2016), was highly variable.

Thus, we hypothesize that multiple oxidation regimes for sulfate formation may indeed coexist in the North China
Plain. The apparent contrasting results could be a consequence of regime transitions between different locations and periods. To test our hypothesis, we have developed a new aerosol water chemistry (AWAC) module and implemented an improved version of ISORROPIA II into the WRF-Chem model (Weather Research and Forecasting model coupled with Chemistry) to better account for the different sulfate formation pathways. With a comprehensive model survey, we focus on the variabilities of aerosol $\mathrm{pH}$ and regimes of sulfate formation in aerosol water with the aim of reconciling the continuing debates on the dominating sulfate formation pathways in the North China Plain. Detailed method description and model evaluation are provided in Sect. 2, followed by the results and discussion in Sect. 3. The last section summarizes the main conclusions and implications of this study.

\section{Method}

\subsection{WRF-Chem-AWAC: new aerosol water chemistry module for WRF-Chem}

To account for the formation of sulfate and nitrate in the liquid water of fine particles (including Aitken and accumulation modes and denoted as $\mathrm{PM}_{2.5}$ ), we have developed a new aerosol water chemistry (AWAC) module into WRF-Chem (version 3.8) (Grell et al., 2005). The coarse mode aerosols have been greatly simplified in the MADE/SORGAM framework, and the AWAC module is therefore not implemented for coarse mode aerosols. For sulfate (denoted as PM25_SO4) formation, we use explicit mechanisms involving 11 irreversible reactions for the oxidation of S(IV) by dissolved $\mathrm{O}_{3}, \mathrm{H}_{2} \mathrm{O}_{2}$, TMI (only $\mathrm{Fe}^{3+}$ and $\mathrm{Mn}^{2+}$ are considered), $\mathrm{NO}_{2}$, and $\mathrm{CH}_{3} \mathrm{OOH}$ (Table 1). The mass transfer of $\mathrm{SO}_{2}$ and gaseous oxidants between gas and liquid phases, as well as the dissociation equilibrium of sulfurous acid, is treated as an irreversible reaction and solved simultaneously with the redox reactions using KPP software (Damian et al., 2002; Sandu and Sander, 2006) and the Rosenbrock solver (Sandu et al., 1997; Shampine, 1982). The formula for the mass transfer rate coefficient, $k_{\mathrm{T}}$ (in $\mathrm{cm} \mathrm{s}^{-1}$ ), is adopted from Jacob and Brasseur (2017):

$k_{\mathrm{T}}=\left(\frac{R_{\mathrm{d}}}{D_{\mathrm{g}}}+\frac{0.04}{\alpha \sqrt{8 R T / \pi M_{\mathrm{w}}}}\right)^{-1}$,

where $R_{\mathrm{d}}$ is the mean radius for fine particles (including aerosol water; in $\mathrm{cm}), D_{\mathrm{g}}$ is the molecular diffusion coefficient $\left(\mathrm{cm}^{2} \mathrm{~s}^{-1}\right), R$ is the gas constant $\left(8.314 \mathrm{~J} \mathrm{~mol}^{-1} \mathrm{~K}^{-1}\right)$, $T$ is the air temperature $(\mathrm{K}), M_{\mathrm{w}}$ is the molecular weight $\left(\mathrm{kg} \mathrm{mol}^{-1}\right)$, and $\alpha$ is the mass accommodation coefficient (unitless). Detailed descriptions are provided in the Supplement (Figs. S1-S5 and Tables S1-S5). Although using different solvers, the box model version of the aerosol water chemistry module could reproduce well the results in Cheng et al. (2016) (shown in Fig. S5 of Supplement). 
Table 1. Rate expressions and rate constants for the S(IV) oxidation reactions in the aerosol water.

\begin{tabular}{|c|c|c|}
\hline Oxidants & Rate expression & References \\
\hline $\mathrm{O}_{3}$ & $\begin{array}{l}r_{\mathrm{O}_{3}}+\mathrm{S}(\mathrm{IV})=\left(k_{0}\left[\mathrm{SO}_{2} \cdot \mathrm{H}_{2} \mathrm{O}\right]+k_{1}\left[\mathrm{HSO}_{3}^{-}\right]+k_{2}\left[\mathrm{SO}_{3}^{2-}\right]\right)\left[\mathrm{O}_{3}(\mathrm{aq})\right] \\
k_{0}=2.4 \times 10^{4} \mathrm{M}^{-1} \mathrm{~s}^{-1} \\
k_{1}=3.7 \times 10^{5} \mathrm{M}^{-1} \mathrm{~s}^{-1}, E / R=5530 \mathrm{~K} \\
k_{2}=1.5 \times 10^{9} \mathrm{M}^{-1} \mathrm{~s}^{-1}, E / R=5280 \mathrm{~K}\end{array}$ & Seinfeld and Pandis (2016) \\
\hline $\mathrm{H}_{2} \mathrm{O}_{2}$ & $\begin{array}{l}r_{\mathrm{H}_{2} \mathrm{O}_{2}+\mathrm{S}(\mathrm{IV})}=\left(k_{3}\left[\mathrm{H}^{+}\right]\left[\mathrm{HSO}_{3}^{-}\right]\left[\mathrm{H}_{2} \mathrm{O}_{2}(\mathrm{aq})\right]\right) /\left(1+13 \cdot\left[\mathrm{H}^{+}\right]\right) \\
k_{3}=7.45 \times 10^{7} \mathrm{M}^{-1} \mathrm{~s}^{-1}, E / R=4430 \mathrm{~K}\end{array}$ & Seinfeld and Pandis (2016) \\
\hline TMI & $\begin{array}{l}r_{\mathrm{TMI}+\mathrm{S}(\mathrm{IV})}=\left\{\begin{array}{c}k_{4}\left[\mathrm{H}^{+}\right]^{-0.74}\left[\mathrm{Mn}^{2+}\right]\left[\mathrm{Fe}^{3+}\right][\mathrm{S}(\mathrm{IV})] \mathrm{pH} \leq 4.2 \\
k_{5}\left[\mathrm{H}^{+}\right]^{0.67}\left[\mathrm{Mn}^{2+}\right]\left[\mathrm{Fe}^{3+}\right][\mathrm{S}(\mathrm{IV})] \mathrm{pH}>4.2\end{array}\right. \\
k_{4}=3.72 \times 10^{7} \mathrm{M}^{-1.26} \mathrm{~s}^{-1} \\
k_{5}=2.51 \times 10^{13} \mathrm{M}^{-2.67} \mathrm{~s}^{-1}\end{array}$ & $\begin{array}{l}\text { Ibusuki and Takeuchi (1987) } \\
\text { Cheng et al. (2016) }\end{array}$ \\
\hline $\mathrm{NO}_{2}^{*}$ & $\begin{array}{l}r_{\mathrm{NO}_{2}+\mathrm{S}(\mathrm{IV})}=k_{6}\left[\mathrm{NO}_{2}(\mathrm{aq})\right][\mathrm{S}(\mathrm{IV})] \\
\text { Lower estimate: } k_{6, \text { low }}=(0.14-2) \times 10^{6} \mathrm{M}^{-1} \mathrm{~s}^{-1} \\
\text { Higher estimate: } k_{6, \text { high }}=(1.24-1.67) \times 10^{7} \mathrm{M}^{-1} \mathrm{~s}^{-1} \\
k_{6} \text { is the average of } k_{6, \text { low }} \text { and } k_{6, \text { high }}\end{array}$ & $\begin{array}{l}\text { Seinfeld and Pandis (2016) } \\
\text { Lee and Schwartz (1983) } \\
\text { Clifton et al. (1988) } \\
\text { Cheng et al. (2016) }\end{array}$ \\
\hline $\mathrm{CH}_{3} \mathrm{OOH}$ & $\begin{array}{l}r_{\mathrm{CH}_{3} \mathrm{OOH}+\mathrm{S}(\mathrm{IV})}=k_{7}\left[\mathrm{H}^{+}\right]\left[\mathrm{HSO}_{3}^{-}\right]\left[\mathrm{CH}_{3} \mathrm{OOH}\right] \\
k_{7}=1.75 \times 10^{7} \mathrm{M}^{-2} \mathrm{~s}^{-1}, E / R=3801 \mathrm{~K}\end{array}$ & Walcek and Taylor (1986) \\
\hline $\begin{array}{l}\text { The rate coeffic } \\
6=\left\{\begin{array}{l}\left(k_{6, \text { low }},\right. \\
\left(k_{6, \text { low }},\right. \\
\left(k_{6, \text { low }},\right. \\
\left(k_{6, \text { low }},\right. \\
\left(k_{6, \text { low }},\right.\end{array}\right.\end{array}$ & $\begin{array}{l}\text { ient } k_{6}\left(\mathrm{in} \mathrm{M}^{-1} \mathrm{~s}^{-1}\right) \text { is expressed as follows: } \\
\left.+k_{6, \text { high, } 1}\right) / 2 \quad \mathrm{pH} \leq 5 \\
\left.+(\mathrm{pH}-5) / 0.8 \times\left(k_{6, \text { low }, 2}-k_{6, \text { low }, 1}\right)+k_{6, \text { high, } 1}\right) / 2 \quad 5<\mathrm{pH} \leq 5.3 \\
\left.+(\mathrm{pH}-5) / 0.8 \times\left(k_{6, \text { low, }}-k_{6, \text { low }, 1}\right)+k_{6, \text { high, } 1}+(\mathrm{pH}-5.3) / 3.4 \times\left(k_{6, \text { high, } 2}-k_{6, \text { high, } 1}\right)\right) / 2 \\
\left.+(\mathrm{pH}-5.3) / 3.4 \times\left(k_{6, \text { high, } 2}-k_{6, \text { high, } 1}\right)\right) / 2 \quad 5.8<\mathrm{pH} \leq 8.7 \\
\left.+k_{6, \text { high, }, 2}\right) / 2 \mathrm{pH}>8.7\end{array}$ & $5.3<\mathrm{pH} \leq 5.8$ \\
\hline
\end{tabular}

Following B. Zheng et al. (2015) and Chen et al. (2016), a parameterization scheme is adopted to simulate the aqueousphase production of nitrate (denoted as PM25_NO3):

$\frac{\mathrm{d} C_{\mathrm{PM} 25 \_\mathrm{NO} 3}}{\mathrm{~d} t}=\left(\frac{R_{\mathrm{d}}}{D_{\mathrm{g}, \mathrm{NO}_{2}}}+\frac{0.04}{\gamma_{\mathrm{NO}_{2}} \sqrt{8 R T / \pi M_{\mathrm{w}, \mathrm{NO}_{2}}}}\right)^{-1}$

$\cdot \mathrm{Aa} \cdot C_{\mathrm{NO}_{2}(\mathrm{~g})}$

where Aa is the surface area concentration of fine particles $\left(\mathrm{cm}^{2} \mathrm{~cm}^{-3}\right)$ and $\gamma$ is the uptake coefficient (unitless) for $\mathrm{NO}_{2}$. The uptake coefficient $\gamma$ has a lower limit $\left(3.0 \times 10^{-6}\right)$ and a higher limit $\left(13.0 \times 10^{-6}\right)$ when the relative humidity $(\mathrm{RH})$ is lower than $50 \%$ and higher than $90 \%$, respectively. Note that the $\gamma$ has been scaled 15 times lower than that used in B. Zheng et al. (2015) to better match the observed PM25_NO3 with $R=0.74$ and NMB $=3 \%$ (normalized mean bias; see more details in Sect. 3.1). When the RH ranges between $50 \%$ and $90 \%$, the value for $\gamma$ is then linearly interpolated between the two limits.

To simulate aerosol water content (AWC) and $\mathrm{pH}$ as input parameters of the AWAC module, we have replaced the original ISORROPIA model in WRF-Chem with an improved version of ISORROPIA II (Fountoukis and Nenes, 2007; Song et al., 2018). The source code of the improved ISORROPIA II is available at http://wiki.seas.harvard.edu/
geos-chem/index.php/ISORROPIA_II (last access: 6 October 2020). ISORROPIA predicts the thermodynamic equilibrium (including $\mathrm{pH}$ ) for an internal-mixed system of multiple inorganic components at a specific temperature and humidity. Following Ding et al. (2019), we assume that the phase state for aerosol is metastable at $\mathrm{RH}>30 \%$; otherwise the phase state is stable. If the predicted AWC is less than an infinitesimal value (the threshold value of $10^{-8} \mu \mathrm{g} \mathrm{m}^{-3}$ is used; see Figs. S6 and S7 of Supplement for relevant uncertainties), $\mathrm{pH}$ is set to a missing value, and heterogeneous reactions in aerosol water are not calculated. Otherwise the heterogeneous oxidation module is called assuming a fixed number and/or size distribution and thermodynamic status (including $\mathrm{AWC}$ and $\mathrm{pH}$ ) within one time step of the master chemistry module in WRF-Chem program.

The RACM mechanism (Stockwell et al., 1997, 1990) is used to calculate the gas-phase photochemistry and provides the concentrations of gaseous precursors (e.g., $\mathrm{SO}_{2}, \mathrm{NO}_{2}$, etc.) and oxidants (e.g., $\mathrm{O}_{3}, \mathrm{H}_{2} \mathrm{O}_{2}$, etc.). The MADE/SORGAM scheme (Ackermann et al., 1998; Schell et al., 2001) with the improved ISORROPIA II model is used to simulate the aerosol dynamics (including nucleation, coagulation, and condensation) and thermodynamics and provide the aerosol's size distribution and number concentration, as well as $\mathrm{AWC}$ and $\mathrm{pH}$ values. The integrated process rate 
(IPR) technique (Tao et al., 2017, 2015) is used to record the formation rates of sulfuric and nitric acid vapor through photochemical oxidation in the gas phase.

For the TMI oxidation pathway, we assume that $\mathrm{Fe}^{3+}$ and $\mathrm{Mn}^{2+}$ will not be consumed in the TMI pathway due to the catalytic nature of $\mathrm{Fe}^{3+} / \mathrm{Mn}^{2+}$. The concentrations of $\mathrm{Fe}^{3+}$ and $\mathrm{Mn}^{2+}$ (in $\mathrm{mol} \mathrm{L}^{-1}$ ) in aerosol water can be calculated by Eq. (3):

$$
\left\{\begin{array}{c}
{\left[\mathrm{Fe}^{3+}\right]=\operatorname{Min}\left(C_{\mathrm{PM} 25} \mathrm{FE} \cdot \mathrm{FS}_{\mathrm{FE}^{+}} / \mathrm{AWC},\right.} \\
\left.2.6 \times 10^{-38} /\left[\mathrm{OH}^{-}\right]^{3}\right) \\
{\left[\mathrm{Mn}^{2+}\right]=\operatorname{Min}\left(C_{\mathrm{PM} 25} \mathrm{MN}_{\mathrm{MN}} \cdot \mathrm{FS}_{\mathrm{MN}^{+}} / \mathrm{AWC},\right.} \\
\left.1.6 \times 10^{-13} /\left[\mathrm{OH}^{-}\right]^{2}\right)
\end{array},\right.
$$

where PM25_FE and PM25_MN are the fine particle components of Fe and Mn minerals, respectively, $C$ denotes the concentrations in moles per liter of air, $\mathrm{FS}_{\mathrm{FE} 3}+$ and $\mathrm{FS}_{\mathrm{MN} 2}+$ represent the maximum fractional solubility of $\mathrm{Fe}^{3+}$ and $\mathrm{Mn}^{2+}$, respectively (regardless of the acidity of aerosol water), and $\mathrm{AWC}$ is the aerosol liquid water content in liters per liter of air.

\subsection{WRF-Chem model configuration and scenarios}

The modeling framework is constructed on a single domain of 100 (west-east) $\times 70$ (south-north) $\times 30$ (vertical layers) grid cells with a horizontal resolution of $20 \mathrm{~km}$ (including the Gobi Desert; see Fig. S8 of Supplement). The overview of the chemical and physical options used in this study is summarized in Table S6 of Supplement. The Madronich FTUV photolysis scheme (Madronich, 1987) is used to calculate the photolysis rates. The initial and boundary conditions for meteorology and chemistry are derived from $1.0^{\circ} \times 1.0^{\circ}$ National Center for Environmental Prediction Final (NCEP FNL) data and global-scale MOZART outputs, respectively. Observation nudging (Liu et al., 2005) is used to nudge the modeled temperature, wind fields, and humidity towards the observations (including surface and upper layers). The multiresolution Emission Inventory for China (MEIC) of the year 2013 (Lei et al., 2011; Zhang et al., 2009; Li et al., 2014, $2017 \mathrm{~b}$ ) is used for anthropogenic emissions. The Megan scheme (Guenther et al., 2006) is used for biogenic volatile organic compound emissions. The hourly biomass burning emissions data are provided by the fire inventory from the National Center for Atmospheric Research (NCAR) (FINN; Wiedinmyer et al., 2011). We use the GOCART dust scheme (Ginoux et al., 2001; Zhao et al., 2010, 2013), which is coupled with the MADE/SORGAM aerosol scheme.

In this study, we have simulated 15 scenarios as detailed in Table 2, including an original (ORIG) scenario with WRFChem (original chemistry) and default emissions as mentioned above, a control (CTRL) scenario with WRF-ChemAWAC (with implementation of aerosol water aqueous-phase chemistry) and optimized ammonia emission, as well as additional emissions for chloride and crustal fine particles, and 13 sensitivity scenarios with respect to the CTRL sce- nario. Since anthropogenic source chlorine is not included in MEIC, we adopt the chlorine inventory in Liu et al. (2018), which provides the emissions of $\mathrm{HCl}$ from coal consumption. WRF/Chem prescribes a specific mass ratio of the fine mode dust emission to the total dust emission, and we further adopt the fine mode dust emission speciation profiles from Dong et al. (2016). The mass fractions for fine particle components of $\mathrm{K}, \mathrm{Na}, \mathrm{Ca}, \mathrm{Mg}, \mathrm{Fe}$, and $\mathrm{Mn}$ minerals (denoted as PM25_K, PM25_NA, PM25_CA, PM25_MG, PM25_FE, and PM25_MN, respectively) from dust sources are set as $3.77 \%, 3.94 \%, 7.94 \%, 0.80 \%, 2.43 \%$, and $0.063 \%$, respectively. Dry and wet depositions are also considered for these newly added crustal fine particle components, as detailed in Sect. S2.2 of Supplement.

The CTRL scenario is expected to reproduce the observed fine particle compositions (including sulfate, nitrate, ammonium, chloride, and crustal components) and gas-phase pollutants and thus more reliably predict the spatiotemporal distribution of $\mathrm{pH}, \mathrm{AWC}$, and sulfate production. For this purpose, five parameters in the CTRL scenario have been adjusted to better match the observations (with the criteria that the relative error of the monthly mean concentrations of different fine particle components is less than $5 \%$ ), namely the factor multiplied by the anthropogenic ammonia emissions (denoted as emissf $\mathrm{NH}_{3}$ ), the factor multiplied by dust speciation fractions for PM25_K, PM25_NA, PM_CA and PM25_MG (denoted as emissf plied by the anthropogenic chloride emissions (denoted as

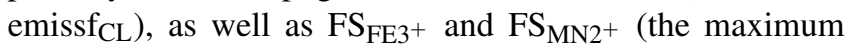
fractional solubility of $\mathrm{Fe}^{3+}$ and $\mathrm{Mn}^{2+}$ in Eq. 3, respectively). In the CTRL scenario, emissf $\mathrm{NH}_{3}$ has been set to 2 as recent studies using top-down inverse modeling (Van Damme et al., 2018; L. Zhang et al., 2018; Wang et al., 2018; Kong et al., 2019) and direct measurement (Wang et al., 2018) found that previous bottom-up inventories might underestimate the $\mathrm{NH}_{3}$ emissions, and the MEIC inventory was estimated to underpredict $\mathrm{NH}_{3}$ emissions by about $40 \%$ over the North China Plain (Kong et al., 2019). As shown in Table S7 of the Supplement, compared to the scenario using the default MEIC emission data, the CTRL scenario (with doubled $\mathrm{NH}_{3}$ emissions) better matches both the observed ammonia and ammonium concentrations at urban Beijing sites during wintertime (Meng et al., 2011; Liu et al., 2017; Song et al., 2018). To match the observations of PM25_OCAT, the emissf OCAT is set to 4.5 (the total dust emission is unchanged) as Dong et al. (2016) indicated that observed fine particles should have a considerably higher mass contribution within the East Asian dust than the chemical transport model prescribes, and emissf $f_{\mathrm{CL}}$ is set to 6 to match the observations of PM25_CL. To have a better agreement with the sulfate observation, $\mathrm{FS}_{\mathrm{FE} 3^{+}}$and $\mathrm{FS}_{\mathrm{MN} 2^{+}}$are set to $7 \%$ and $40 \%$, respectively. Note that the assumption behind tuning only $\mathrm{FS}_{\mathrm{FE} 3}+$ and $\mathrm{FS}_{\mathrm{MN} 2}+$ to better agree with observed sulfates is that the model could reasonably simulate the concentrations of other oxidants (e.g., $\mathrm{OH}, \mathrm{H}_{2} \mathrm{O}_{2}, \mathrm{O}_{3}$, and $\mathrm{NO}_{2}$ ); 
Table 2. Description for different scenarios in this study.

\begin{tabular}{|c|c|c|}
\hline Number & Name & Description \\
\hline 1 & ORIG & $\begin{array}{l}\text { emissf }_{\mathrm{NH}_{3}}=1 \text {, emissf } f_{\mathrm{OCAT}}=0 \text {, emissf } \\
\text { Aqueous-phase oxidation in the aerosol water is excluded. }\end{array}$ \\
\hline 2 & CTRL & $\begin{array}{l}\text { Control experiment is tuned to match the observations at the Beijing TSU site. } \\
\text { A fixed metastable (stable) phase state is assumed if } \mathrm{RH} \text { is greater (not greater) than } \\
30 \% \text {. } \\
\text { emissf }_{\mathrm{NH}_{3}}=2 \text {, emissf } \mathrm{OCAT}=4.5 \text {, emissf } \\
\mathrm{CL}\end{array}$ \\
\hline 3 & MEIC_CTRL & $\begin{array}{l}\text { The same as CTRL except emissf } \mathrm{NH}_{3}=1 \text { (original MEIC inventory), } \mathrm{FS}_{\mathrm{Fe} 3^{+}}= \\
0.35 \% \text {, and } \mathrm{FS}_{\mathrm{MN} 2^{+}}=20 \% \text {. } \\
\text { Another control experiment tuned to match the observations at the Beijing TSU site. }\end{array}$ \\
\hline $4-5$ & $\mathrm{~A} 0, \mathrm{~A} 2$ & The same as CTRL except emissf $\mathrm{NH}_{3}$ is set to zero and doubled, respectively. \\
\hline $6-8$ & OCAT0, OCAT0.5, OCAT2 & The same as CTRL except emissf ${ }_{\text {OCAT }}$ is set to zero, halved, and doubled, respectively. \\
\hline $9-11$ & TMI0, TMI0.5, TMI2 & $\begin{array}{l}\text { The same as CTRL except } \mathrm{FS}_{\mathrm{FE}^{+}} \text {, and } \mathrm{FS}_{\mathrm{MN} 2^{+}} \text {are set to zero, halved, and doubled, } \\
\text { respectively. }\end{array}$ \\
\hline $12-13$ & CL0, CL2 & The same as CTRL except emissf $\mathrm{CL}_{\mathrm{L}}$ is set to zero and doubled, respectively. \\
\hline $14-15$ & MSTB, STB & The same as CTRL except a fixed metastable and stable phase state is assumed. \\
\hline
\end{tabular}

thus, the deviation from observation can be attributed to the uncertainties in representations of the TMI pathway. Note that uncertainties in the emission, transport (i.e., advection and turbulent mixing), removal (dry and wet deposition), and sulfate formation in other phases could also contribute to the discrepancies between modeling results and observations. Nonetheless, this study does not aim to estimate the exact values for aerosol $\mathrm{pH}$ and sulfate formation budget. Instead, this study focuses on investigating the characteristics of the spatiotemporal distribution of aerosol $\mathrm{pH}$, as well as sulfate formation budget, and also the uncertainties relevant to assumptions for input parameters. Journet et al. (2008) found that the dust mineralogy was a critical factor for iron solubility, and fractional Fe solubility was observed to be $\sim 4 \%$ and less than $1 \%$ for samples of clay and iron (hydr-)oxides, respectively. A low fractional Fe solubility approximately or below $0.05 \%$ was reported for the non-atmospherically processed arid soil samples (Schroth et al., 2009; Johnson et al., 2010; Shi et al., 2012). Most of the Fe minerals exist in the form of hematite $\left(\alpha-\mathrm{Fe}_{2} \mathrm{O}_{3}\right)$ over the Gobi Desert (Claquin et al., 1999), and fractional Fe solubility was increased to $1 \%-$ $2 \%$ after 3-5 d transport from the Gobi Desert (Meskhidze et al., 2003). A higher fractional Fe solubility up to $\sim 10 \%$ was reported after a longer time of atmospheric aging for dust particles (Takahashi et al., 2011; Shi et al., 2012). Fractional Mn solubility for dust particles was observed to range between $20 \%$ and $60 \%$ (Duvall et al., 2008; Baker et al., 2006; Hsu et al., 2010). The rest of the 13 scenarios are used for sensitivity analyses on the uncertainties in emissf $\mathrm{NH}_{3}$, emissf $\mathrm{OCAT}$, emissf $\mathrm{CL}_{1}, \mathrm{FS}_{\mathrm{FE} 3^{+}}$, and $\mathrm{FS}_{\mathrm{MN} 2^{+}}$, as well as phase state assumption.

\section{Results and discussion}

\subsection{Comparison of CTRL and ORIG scenarios}

Figure 1 shows the comparison of ORIG and CTRL scenarios against observations obtained at the site located on the campus of Tsinghua University in Beijing (denoted as the Beijing TSU site; $40^{\circ} 00^{\prime} 17^{\prime \prime} \mathrm{N}, 116^{\circ} 19^{\prime} 34^{\prime \prime} \mathrm{E}, \sim 10 \mathrm{~m}$ height) during January 2013. The hourly data include online observations of concentrations of $\mathrm{SO}_{2}, \mathrm{PM} 25 \_\mathrm{SO} 4, \mathrm{NO}_{x}$ (= NO $+\mathrm{NO}_{2}$ ), PM25_NO3, $\mathrm{O}_{3}$, and $\mathrm{PM}_{2.5}$, as well as relative humidity $(\mathrm{RH})$ that is closely related to the AWC. Details about the measurements have been described in G. J. Zheng et al. (2015) and Cheng et al. (2016). As shown in Fig. 1, simulations from both scenarios were capable of reproducing the concentration levels of the sum of $\mathrm{SO}_{2}$ and PM25_SO4, the sum of $\mathrm{NO}_{x}$ and PM25_NO3, $\mathrm{O}_{3}$, and $\mathrm{PM}_{2.5}$ with the normalized mean bias (NMB) around $\pm 30 \%$ and the correlation coefficients $(R)$ ranging between 0.5 and 0.7 . The simulated RH matched the observations well with an NMB of $\sim 12 \%$ and an $R$ of $\sim 0.9$. Simulations of PM25_SO4 and PM25_NO3 have been significantly improved in the CTRL scenario.

Offline observations of PM25_K, PM25_NA, PM25_CA, PM25_MG, PM25_CL, PM25_SO4, PM25_NO3, and PM25_NH4 are also available on a daily basis (G. J. Zheng et al., 2015; Cheng et al., 2016). As shown in Fig. 2, simulations of sulfate, nitrate, and ammonium in $\mathrm{PM}_{2.5}$ were greatly improved in the CTRL scenario with an NMB within $\pm 5 \%$, while the NMB of the ORIG scenario was $-90 \%$ for sulfate, $-35 \%$ for nitrate, and $-65 \%$ for ammonium. The only source of PM25_CL in the ORIG scenario was sea 


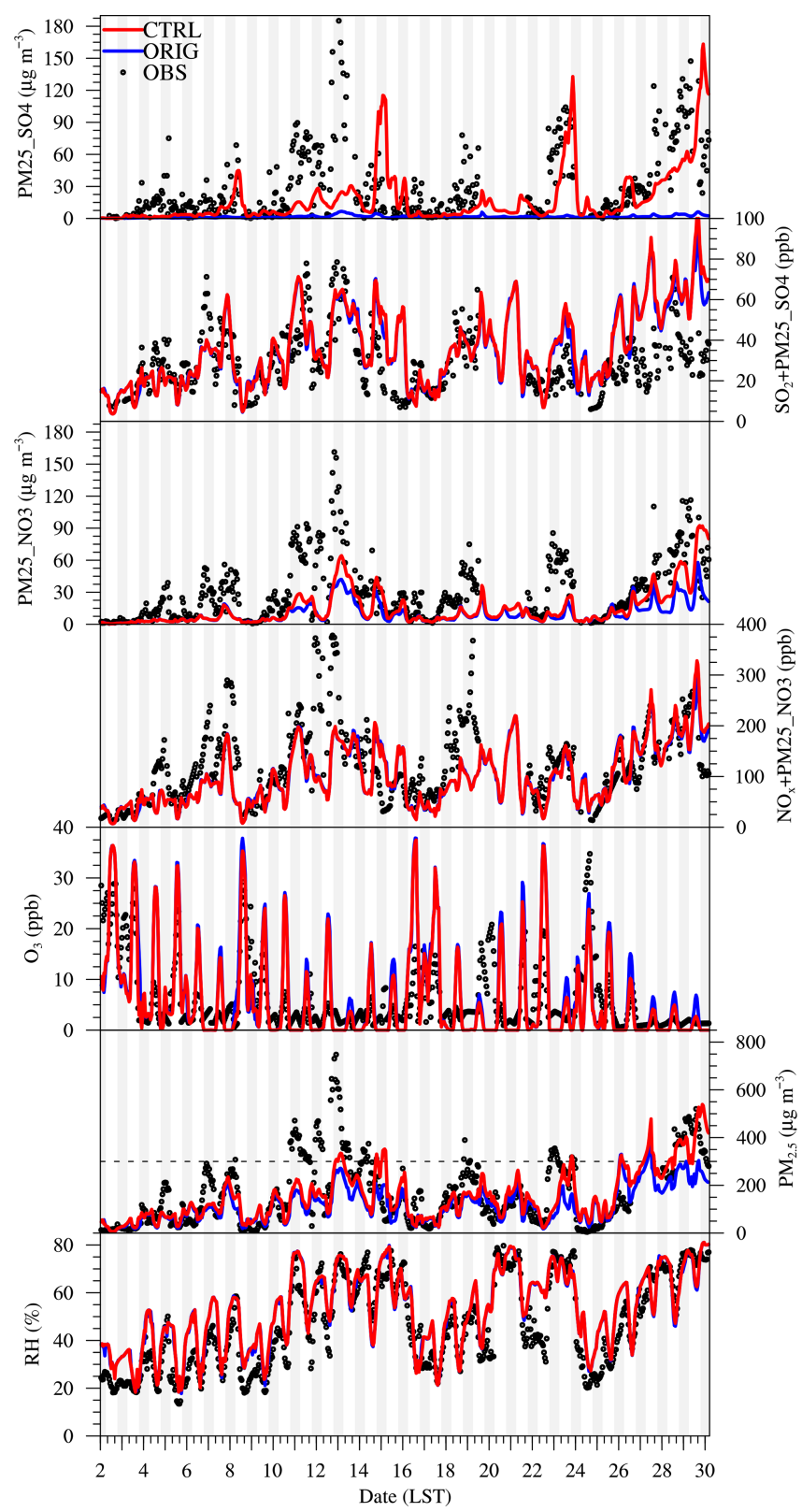

Figure 1. Comparison of hourly model results and observations (OBS) for ORIG and CTRL scenarios at the Beijing TSU site during January 2013. The compared parameters include modeled hourly concentrations of fine particulate sulfate (PM25_SO4), the sum of $\mathrm{SO}_{2}$ and PM25_SO4 (PM25_SO4 converted to the equivalent volume mixing ratio of $\mathrm{SO}_{2}$ ), fine particulate nitrate (PM25_NO3), the sum of $\mathrm{NO}_{x}$ and PM25_NO3 (PM25_NO3 converted to the equivalent volume mixing ratio of $\left.\mathrm{NO}_{x}\right), \mathrm{O}_{3}$, and $\mathrm{PM}_{2.5}$, as well as hourly relative humidity $(\mathrm{RH})$.

salt emissions, and it was negligible. The improved model WRF-Chem-AWAC with additional chloride emissions from coal combustion could capture the observed PM25_CL with an NMB of only $\sim 10 \%$. Other inorganic cations in $\mathrm{PM}_{2.5}$ (denoted as PM25_OCAT and only involving PM25_K,
PM25_NA, PM25_CA, and PM25_MG) were not included in the original MADE/SORGAM scheme, and thus their concentrations were zero in the ORIG scenario. The CTRL scenario could moderately reproduce the concentrations of PM25_OCAT with an NMB of $\sim 60 \%$. Note that the emission of PM25_OCAT has been adjusted based on the criteria of reducing the mismatch of simulation and observation within $5 \%$ on a monthly mean basis, and here the NMB was calculated based on daily values.

As shown in the lower panels of Fig. 2, among the fine particle components mentioned above, observed PM25_NH4 and PM25_OCAT accounted for about $75 \%$ and $25 \%$ of the monthly mean ionic charge budget for cations, respectively. Observed PM25_CL, PM25_NO3, and PM25_SO4 accounted for about $20 \%, 32 \%$, and $48 \%$ of the monthly mean ionic charge budget for anions, respectively. The CTRL scenario could capture well the observed ionic charge budget except that the mole fraction of PM25_CA in PM25_OCAT was slightly overestimated (PM25_CA had a higher mass fraction for dust emission speciation). Thus, in the following sections, the CTRL configuration is used to study the temporal and spatial distribution of aerosol $\mathrm{pH}$ and the regime transition of sulfate formation in aerosol water during winter haze events in the North China Plain.

\subsection{Vertical profile of $\mathrm{pH}$ over Beijing}

Figure 3a shows the vertical profile of the simulated aerosol $\mathrm{pH}$ over the Beijing site. The mean $\mathrm{pH}$ at the surface layer was $\sim 5.4$ (daytime mean $\mathrm{pH} \sim 5.2$ and nighttime mean $\mathrm{pH}$ $\sim 5.6$ ), and it remained nearly constant around $\sim 5$ up to $\sim 2 \mathrm{~km}$ above ground level (a.g.l.), while above $\sim 2 \mathrm{~km}$ a.g.l., the mean $\mathrm{pH}$ exhibited a more rapid decrease and became highly acidic (mean $\mathrm{pH} \sim 0$ ) at $\sim 3 \mathrm{~km}$ a.g.l. Based on observations of aerosol compositions, Guo et al. (2016) also reported that $\mathrm{pH}$ at the middle troposphere of $5 \mathrm{~km}$ a.g.l. was highly acidic (mean $\mathrm{pH} \sim-0.7$ ) and was about 1.7 units lower than at the surface layer over the northeastern Unites States. These spatial features for $\mathrm{pH}$ were closely associated with the spatiotemporal variation in the abundance of acidic and alkaline fine particle components and their gaseous counterparts. Here, the acidic fine particle components include total sulfate $\left(\mathrm{SO}^{\mathrm{T}}=\mathrm{H}_{2} \mathrm{SO}_{4}(\mathrm{~g})+\mathrm{PM} 25 \_\mathrm{SO} 4\right)$, total nitrate $\left(\mathrm{NO}^{\mathrm{T}}=\mathrm{HNO}_{3}(\mathrm{~g})+\mathrm{PM} 25 \_\mathrm{NO} 3\right)$, and total chloride $\left(\mathrm{Cl}^{\mathrm{T}}\right.$ $=\mathrm{HCl}(\mathrm{g})+$ PM25_CL $)$, and the alkaline components include total ammonia $\left(\mathrm{NH}_{x}=\mathrm{NH}_{3}(\mathrm{~g})+\mathrm{PM} 25 \_\mathrm{NH} 4\right)$ and PM25_OCAT. 


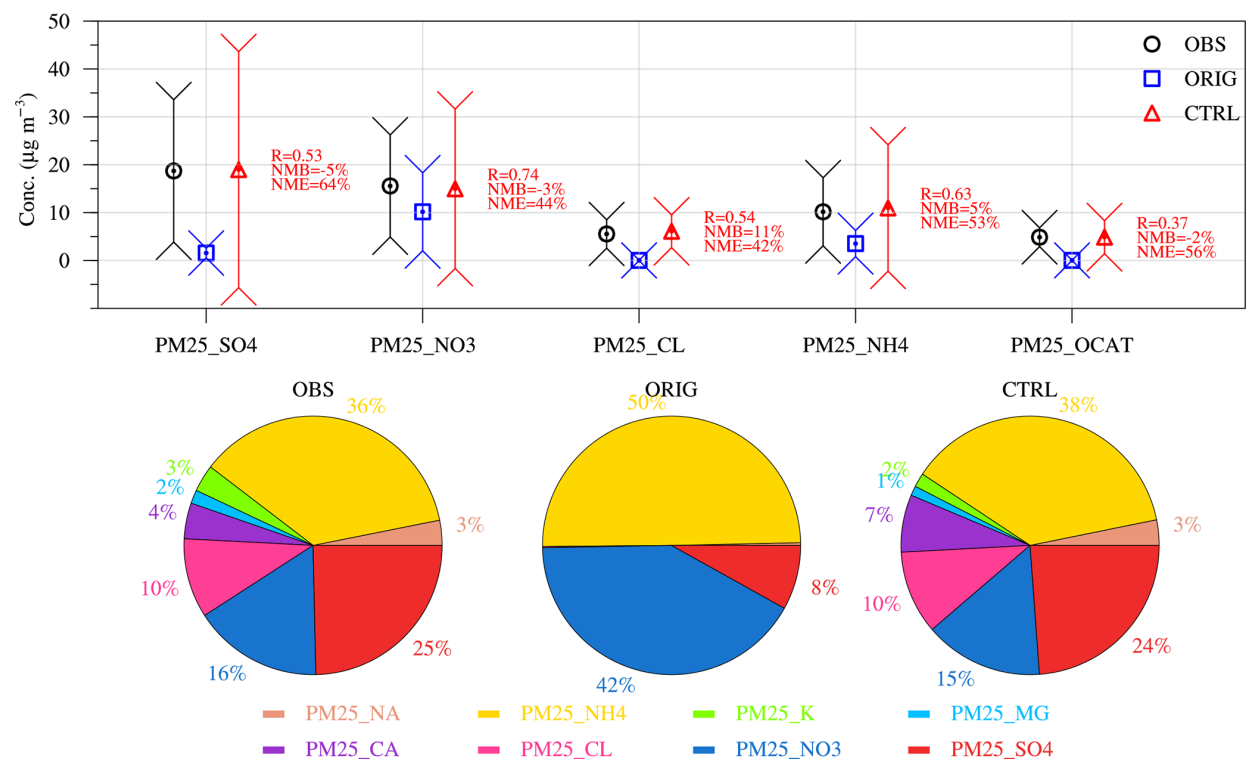

Figure 2. The significant improvement of simulations in the CTRL scenario compared to the ORIG scenario. Bottom panel: observed (OBS) and simulated (scenarios of ORIG and CTRL) mean electric charge fractions for fine particulate sulfate (PM25_SO4, using SO ${ }_{4}^{2-}$ as the surrogate), nitrate (PM25_NO3), ammonium (PM25_NH4), chloride (PM25_CL), sodium (PM25_NA), potassium (PM25_K), calcium (PM25_CA), and magnesium (PM25_MG) at the Beijing TSU site during January 2013. Top panel: observed (OBS) and simulated (scenarios of ORIG and CTRL) concentrations (both average and standard deviation are shown) for fine particulate sulfate (PM25_SO4), nitrate (PM25_NO3), chloride (PM25_CL), ammonium (PM25_NH4) and other cation components (PM25_OCAT = PM25_NA + PM25_K + PM25_CA + PM25_MG) at the Beijing TSU site during January 2013.

Thus, we define the concentrations of total potential anion $\left(\right.$ anion $\left.^{\mathrm{T}}\right)$ and total potential cation $\left(\right.$ cation $\left.^{\mathrm{T}}\right)$ as follows:

$$
\begin{aligned}
C_{\text {anion }^{\mathrm{T}}}= & 2 \cdot C_{\mathrm{SO} 4{ }^{\mathrm{T}}}+C_{\mathrm{NO}^{\mathrm{T}}}+C_{\mathrm{Cl}^{\mathrm{T}}}, \\
C_{\text {cation }^{\mathrm{T}}=}= & C_{\mathrm{NH}_{\mathrm{x}}}+C_{\mathrm{PM} 25 \_\mathrm{NA}}+C_{\mathrm{PM} 25 \_\mathrm{K}} \\
& +2 \cdot C_{\mathrm{PM} 25 \_\mathrm{MG}}+2 \cdot C_{\mathrm{PM} 25 \_\mathrm{CA}} .
\end{aligned}
$$

As shown in Fig. $3 b-c$, the concentration ratio of cation ${ }^{\mathrm{T}}$ to anion ${ }^{\mathrm{T}}$ slightly changed (consistently decreased with increasing height at nighttime but firstly decreased and then increased with the increasing height in daytime) below $2 \mathrm{~km}$ a.g.l. and rapidly decreased above $\sim 2 \mathrm{~km}$ a.g.l. $\mathrm{NH}_{x}$ had the predominant mole fraction in the sum of anion ${ }^{\mathrm{T}}$ and cation $^{\mathrm{T}}$ below the lower free troposphere (below $\sim$ $1 \mathrm{~km}$ a.g.l.), but its concentrations decreased sharply with the increasing height (Fig. 3e) as ammonia only had surface emissions. Although also dominated by the surface emission source of $\mathrm{SO}_{2}$ and $\mathrm{NO}_{x}$, both $\mathrm{SO}^{\mathrm{T}}\left(=\mathrm{H}_{2} \mathrm{SO}_{4}(\mathrm{~g})+\right.$ PM25_SO4) and $\mathrm{NO}^{\mathrm{T}}\left(=\mathrm{HNO}_{3}(\mathrm{~g})+\mathrm{PM} 25 \_\mathrm{NO} 3\right)$ could be produced through different gas-phase and aqueous-phase oxidation pathways at different altitudes. Thus, although their concentrations also decreased with the increasing altitude (Fig. 3d), the decreasing rate was slower than that of $\mathrm{NH}_{x}$ (Fig. 3d-e), which led to an increase in the mole fraction of anion ${ }^{\mathrm{T}}$ above $\sim 2 \mathrm{~km}$ a.g.l. (Fig. $3 \mathrm{~b}-\mathrm{c}$ ). The vertical profile of PM25_OCAT was distinct from that of $\mathrm{NH}_{x}$ (Fig. 3e), with its concentrations remaining almost constant until $\sim 1.5 \mathrm{~km}$ a.g.l. and decreasing relatively slowly above it, suggesting a different source possibly from high-altitude transport. Based on satellite, lidar, and surface measurement data, Huang et al. (2008) studied the vertical structure of Asian dust originating from the Taklamakan and Gobi deserts and found that dust particles could be uplifted to an altitude of $\sim 9 \mathrm{~km}$ around the source region, followed by the efficient eastward transport mainly via westerly jets. X.$X$. Zhang et al. (2018) also investigated the dust layering structure over some cities in East Asia (including Beijing, Seoul, and Tokyo) and indicated that the dust particles were mixed well in the boundary layer before the intensive intermingling of subsiding layers from above (the passage of a dust storm). Our simulation also shows that PM25_OCAT over the Beijing site was evenly mixed after a long-range transport from its source region (mainly in the Gobi Desert; shown in Fig. S9 of the Supplement) below the lower free troposphere. Under different environmental conditions, the changes in concentrations and mole fractions of acidic and alkaline components could lead to competition and different dominant factors in the changes of $\mathrm{pH}$ vertically. Above $\sim 2 \mathrm{~km}$, the influences of acidic components (mainly SO $4^{\mathrm{T}}$ and $\mathrm{NO}^{\mathrm{T}}$ ) on $\mathrm{pH}$ eventually prevailed over those of alkaline components. Interestingly, PM25_OCAT could play a key role in maintaining a less acidic $\mathrm{pH}$ at $\sim 1.5-2.0 \mathrm{~km}$ a.g.l. A sensitivity test shows that if the PM25_OCAT is completely removed (in OCAT0 scenario), $\mathrm{pH}$ at $2.0 \mathrm{~km}$ a.g.l. would be $\sim 1$ unit lower (more acidic) than that at $1.5 \mathrm{~km}$ a.g.l. 

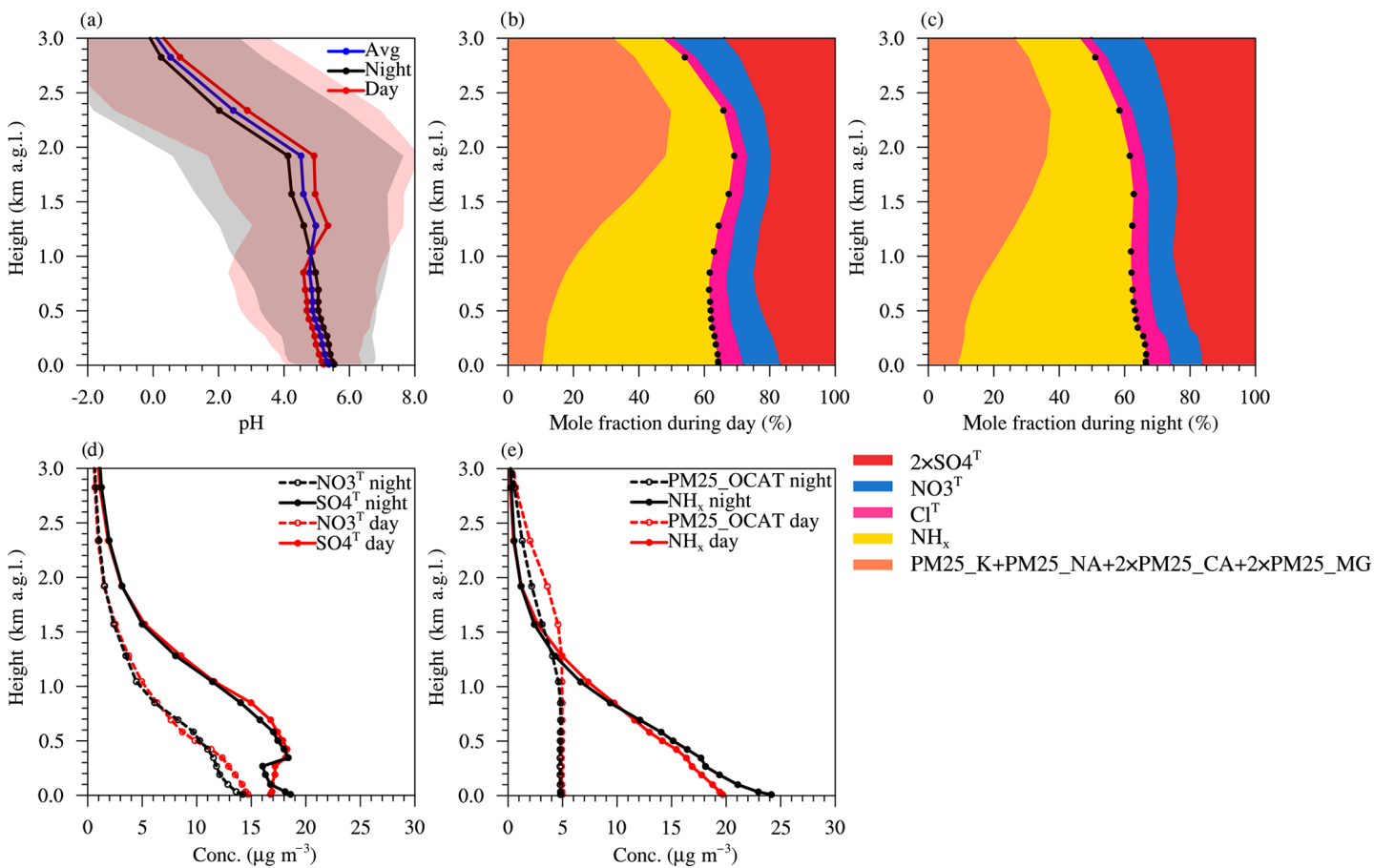

Figure 3. Vertical profiles of the fine particle $\mathrm{pH}$ and its potential influencing factors over the Beijing TSU site. The data are simulated with the CTRL scenario during January 2013 and presented at height above ground level (a.g.1.). (a) Monthly average pH (blue), as well as daytime (red) and nighttime (black) average $\mathrm{pH}$ (standard deviations are shown in light red and light gray shading, respectively). (b) Daytime mole fractions for the electric charge of total ammonia $\left(\mathrm{NH}_{x}\right)$, total chloride $\left(\mathrm{Cl}^{\mathrm{T}}\right)$, total sulfate $\left(\mathrm{SO} 4^{\mathrm{T}}\right)$, total nitrate $\left(\mathrm{NO} 3^{\mathrm{T}}\right)$, and different crustal components of $\mathrm{PM}_{2.5}$, and the black dots represent the vertical profile of cation ${ }^{\mathrm{T}} /\left(\right.$ cation $^{\mathrm{T}}+$ anion $\left.^{\mathrm{T}}\right)$. (c) The same as in (b) but for the nighttime. (d) Daytime (red) and nighttime (black) concentrations of total sulfate $\left(\mathrm{SO}^{\mathrm{T}}\right)$ and total nitrate $\left(\mathrm{NO} 3^{\mathrm{T}}\right)$. $(\mathbf{e}) \mathrm{Daytime}(\mathrm{red})$ and nighttime (black) concentrations of $\mathrm{NH}_{x}$ and PM25_OCAT.

\subsection{Diurnal cycle of pH over Beijing}

Figure 3a shows that at the Beijing site, the nighttime $\mathrm{pH}$ was slightly higher than the daytime $\mathrm{pH}$ below $\sim 1 \mathrm{~km}$ a.g.l. but became lower above $\sim 1 \mathrm{~km}$. As shown in Fig. 4 , such an opposite pattern was largely driven by a different diurnal cycle of aerosol $\mathrm{pH}$ at different altitudes. Aerosol $\mathrm{pH}$ at the surface layer showed a minimum in the early afternoon, while at $2 \mathrm{~km}$ it showed a maximum around this time (Fig. $4 \mathrm{a}-\mathrm{b}$ ). The diurnal variation of $\mathrm{pH}$ also showed a highly similar pattern as the mole ratio of cation ${ }^{\mathrm{T}}$ to anion ${ }^{\mathrm{T}}$ (Fig. 4a-b). At the surface layer, concentrations of cation ${ }^{\mathrm{T}}$ were considerably higher than concentrations of anion ${ }^{\mathrm{T}}$ (Fig. 4d); furthermore, the diurnal variation of $\mathrm{NH}_{x}$ to a large extent explained the diurnal cycle pattern of cation ${ }^{\mathrm{T}}$. Daytime $\mathrm{NH}_{x}$ concentrations were significantly lower than at nighttime due to stronger boundary layer mixing. Following Song et al. (2018), we define the concentrations of required $\mathrm{NH}_{x}$ $\left(\mathrm{NH}_{x}^{\mathrm{Req}}\right)$ as follows:

$$
\begin{aligned}
C_{\mathrm{NH}_{x}^{\mathrm{Req}}=}= & 2 \cdot C_{\mathrm{SO} 4^{\mathrm{T}}}+C_{\mathrm{NO}^{\mathrm{T}}}+C_{\mathrm{Cl}^{\mathrm{T}}}-C_{\mathrm{PM} 25 \_\mathrm{NA}} \\
& -C_{\mathrm{PM} 25 \_\mathrm{K}}-2 \cdot C_{\mathrm{PM} 25 \_\mathrm{MG}}-2 \cdot C_{\mathrm{PM} 25 \_\mathrm{CA}} .
\end{aligned}
$$

The physical meaning of $\mathrm{NH}_{x}^{\mathrm{Req}}$ is that the minimum $\mathrm{NH}_{x}$ ideally immobilizes all the gas-phase $\mathrm{H}_{2} \mathrm{SO}_{4}, \mathrm{HNO}_{3}$ and $\mathrm{HCl}$. Thus, the concentration ratio of $\mathrm{NH}_{x}^{\mathrm{Req}}$ to $\mathrm{NH}_{x}$ describes the levels of ammonia excess (Liu et al., 2017; Song et al., 2018). The diurnal cycles of $\mathrm{pH}$ and ammonia excess matched quite well with each other (Fig. 4b), and enhanced ammonia excess corresponded with a higher $\mathrm{pH}$ during nighttime. PM25_OCAT (mainly originating from long-range transport) concentrations were higher in daytime. $\mathrm{SO}^{\mathrm{T}}$ rapidly accumulated during the night (when the aqueous-phase production was active), while $\mathrm{NO}^{\mathrm{T}}$ concentrations reached their peak in the late afternoon (gasphase oxidation played a more important role). As shown in Fig. 4c, a higher aerosol water content during nighttime (due to higher $\mathrm{RH}$ and $\mathrm{PM}_{2.5}$ loading) would also contribute to the less acidic condition (G. J. Zheng et al., 2020). At the layer of $\sim 2 \mathrm{~km}$ a.g.l., the $\mathrm{pH}$ diurnal cycle was also similarly associated with the variation in the mole ratio of cation ${ }^{\mathrm{T}}$ to anion $^{\mathrm{T}}$ (peaks around noon), and the diurnal variation of PM25_OCAT might play an important role. 


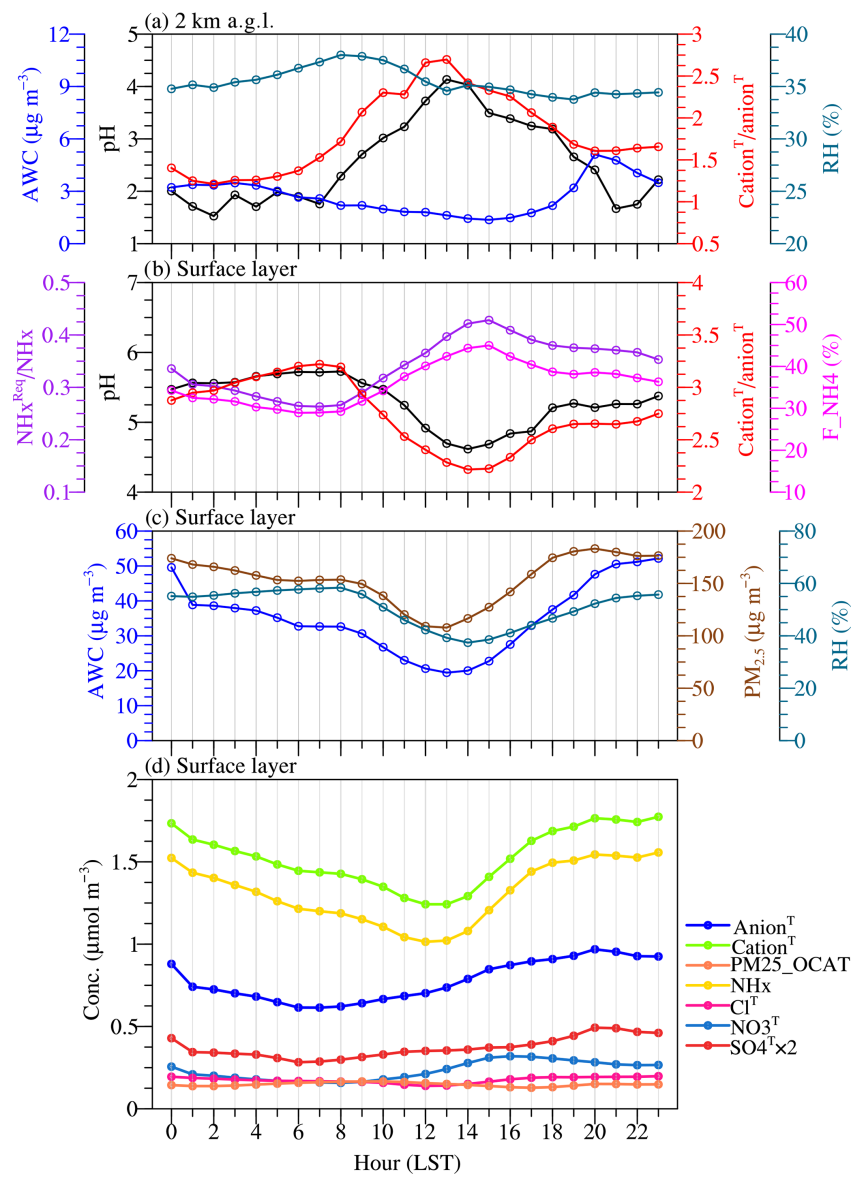

Figure 4. Monthly mean diurnal cycle for (a) fine particle $\mathrm{pH}$, aerosol liquid water content (AWC), the mole ratio of total potential cation $\left(\right.$ cation $^{\mathrm{T}}$ ) to total potential anion $\left(\right.$ anion $^{\mathrm{T}}$ ), and relative humidity $(\mathrm{RH})$ at $2 \mathrm{~km}$ a.g.l., (b) fine particle $\mathrm{pH}$, the mole ratio of cation $^{\mathrm{T}}$ to anion ${ }^{\mathrm{T}}$, the mole ratio of required $\mathrm{NH}_{x}\left(\mathrm{NH}_{x}^{\mathrm{Req}}\right)$ to $\mathrm{NH}_{x}$, and fraction of $\mathrm{NH}_{x}$ in the particle phase (F_NH4) at the surface layer, (c) AWC, $\mathrm{RH}$, and $\mathrm{PM}_{2.5}$ concentrations at the surface layer, and $(\mathbf{d})$ concentrations of total sulfate $\left(\mathrm{SO}^{\mathrm{T}}\right)$, total nitrate $\left(\mathrm{NO}^{\mathrm{T}}\right)$, total chloride $\left(\mathrm{Cl}^{\mathrm{T}}\right)$, total ammonia $\left(\mathrm{NH}_{x}\right), \mathrm{PM} 25$ _OCAT, cation ${ }^{\mathrm{T}}$, and anion ${ }^{\mathrm{T}}$ at the surface layer simulated in the CTRL scenario at the Beijing TSU site during January 2013.

\subsection{Variabilities of $\mathrm{pH}$ over the North China Plain}

Figure $5 \mathrm{a}-\mathrm{b}$ show that aerosol $\mathrm{pH}$ at the surface layer exhibited a large spatial variability in the North China Plain. High $\mathrm{pH}$ greater than 6 was found in areas north of $\sim 41^{\circ} \mathrm{N}$, which could be attributed to abundant crustal components originating from dust and low concentrations of other aerosol inorganic compositions due to low emissions of precursors (e.g., $\mathrm{SO}_{2}, \mathrm{NO}_{x}$, and $\mathrm{NH}_{3}$ ). In areas south of $\sim 41^{\circ} \mathrm{N}$, mean aerosol $\mathrm{pH}$ fell mostly between 4.4 and $5.7(10 \%$ and $90 \%$ quantiles, respectively) with less contribution from crustal components. Mean $\mathrm{pH}$ over the sea mainly ranged between 4.0 and 4.5, generally lower than over most terrestrial areas. These marine and terrestrial areas with a relatively more acidic aerosol phase ( $\mathrm{pH} \sim 4.0$ to 5.0 ) corresponded well with the spatial distribution of low $\mathrm{NH}_{x}$ zones (Fig. 5d). Moreover, a large temporal variability of $\mathrm{pH}$ was also found at the surface layer (Fig. 5c). The simulated standard deviation of $\mathrm{pH}$ mostly ranged between 0.4 and 2 and was higher over the northern areas with episodic dust events, as well as the southern areas with lower $\mathrm{NH}_{x}$ emissions.

Figure 6a shows the latitude-height cross section of aerosol $\mathrm{pH}$ in the North China Plain. The trend that aerosol acidity was enhanced with increasing altitude was consistent for all the latitudes investigated. Nonetheless, the vertical gradients of $\mathrm{pH}$ varied among different locations and were closely associated with the vertical profile of the relative abundance of cation ${ }^{\mathrm{T}}$ and anion ${ }^{\mathrm{T}}$, as well as air temperature and humidity (Fig. S10 of Supplement). Figure 6b further compares the vertical profiles of aerosol $\mathrm{pH}$ over seven different cities in the North China Plain (locations shown in Fig. 5c). The vertical profile pattern of aerosol $\mathrm{pH}$ was highly similar among Beijing, Tianjin, Baoding, and Shijiazhuang, for which the $\mathrm{pH}$ changed slightly until above $\sim 2 \mathrm{~km}$ a.g.l. However, as shown in Figs. $5 \mathrm{c}$ and $\mathrm{S} 10$, pH decreased rapidly from 1 to $2 \mathrm{~km}$ a.g.l. over both Zhangjiakou and Taiyuan maybe due to the lack of alkaline fine particle components $\left(\mathrm{NH}_{x}\right.$ or PM25_OCAT). The rapid production of sulfate and nitrate at $0.5-1 \mathrm{~km}$ a.g.l. over Jinan was observed (Fig. S10), leading to a lower pH there. Furthermore, monthly mean nighttime $\mathrm{pH}$ was mostly higher than daytime $\mathrm{pH}$ in the lowest boundary layer below $\sim 100 \mathrm{~m}$ a.g.l.; however, no consistent pattern was found for the diurnal cycle pattern of $\mathrm{pH}$ in the upper tropospheric layers (Fig. 6c).

\subsection{Regime transition of sulfate formation}

Figure 7a shows the averaged contribution of six sulfate formation pathways, namely aerosol water-phase oxidation by dissolved $\mathrm{O}_{3}, \mathrm{NO}_{2}, \mathrm{H}_{2} \mathrm{O}_{2}$, TMI (in the presence of $\mathrm{O}_{2}$ ), and $\mathrm{CH}_{3} \mathrm{OOH}$, as well as gas-particle partitioning of $\mathrm{H}_{2} \mathrm{SO}_{4}$ vapor (GPP) at the surface layer. Note that $\mathrm{H}_{2} \mathrm{SO}_{4}$ vapor is produced mainly from the oxidation of $\mathrm{SO}_{2}$ by $\mathrm{OH}$ radical and then partitions almost completely into the aerosol phase. For areas north of $41^{\circ} \mathrm{N}$, oxidation by dissolved $\mathrm{O}_{3}$ was the most important pathway, followed by the TMI pathway. To the south of $41^{\circ} \mathrm{N}, \mathrm{NO}_{2}$, TMI, and $\mathrm{H}_{2} \mathrm{O}_{2}$ pathways played the dominant role. The $\mathrm{NO}_{2}$ reaction pathway prevailed in the megacity region of Beijing and the large area of Hebei Province to the south and west of Beijing, as well as part of Shandong Province, while the TMI pathway dominated in the inland region to the west and the coastal regions to the east of Beijing, and the $\mathrm{H}_{2} \mathrm{O}_{2}$ pathway dominated in the region further south in Shandong and Henan provinces. The regime transition of sulfate formation pathways were highly dependent on the spatial distribution of $\mathrm{pH}$ and oxidants and catalysts. As shown in Fig. 7b-e, the spatial distribution for $\mathrm{O}_{3}$ exhibited an opposite pattern as $\mathrm{NO}_{x}$; i.e., $\mathrm{O}_{3}$ concentrations in urbanized areas (e.g., Beijing) with high $\mathrm{NO}_{x}$ emis- 


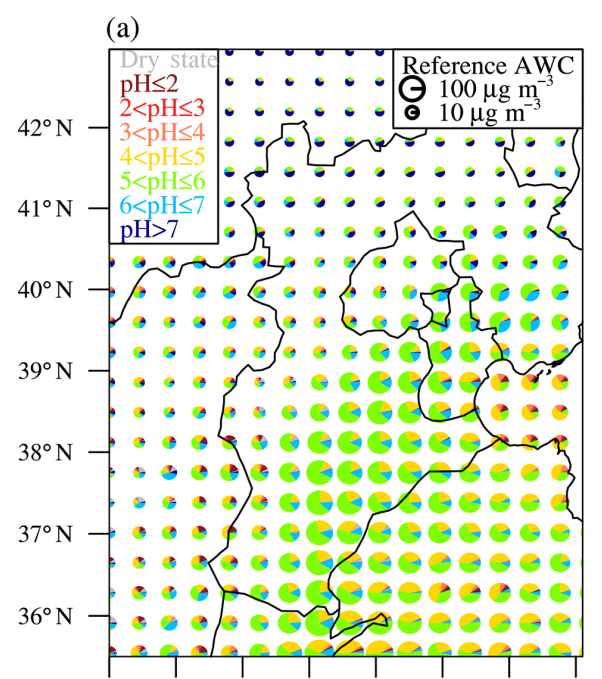

$112^{\circ} \mathrm{E} 113^{\circ} \mathrm{E} 114^{\circ} \mathrm{E} 115^{\circ} \mathrm{E} 116^{\circ} \mathrm{E} 117^{\circ} \mathrm{E} 118^{\circ} \mathrm{E} 119^{\circ} \mathrm{E}$

(c)

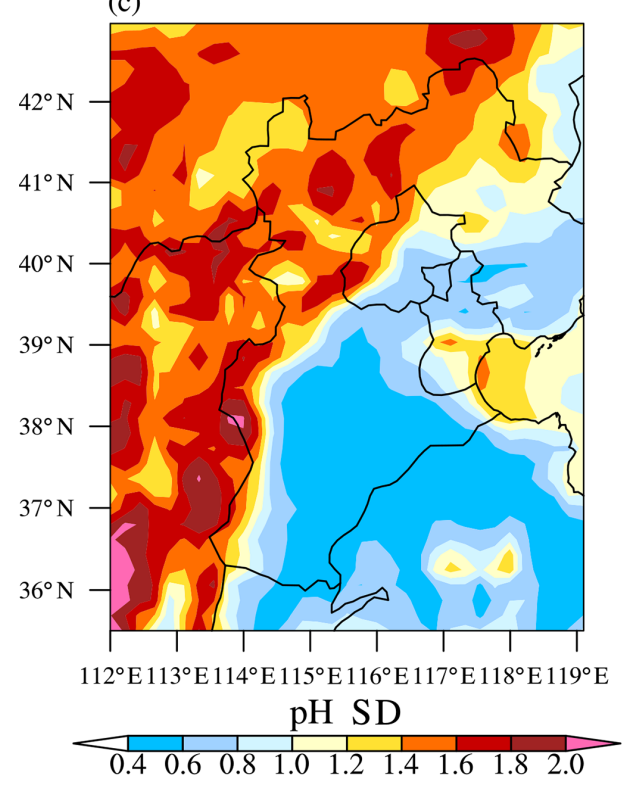

(b)

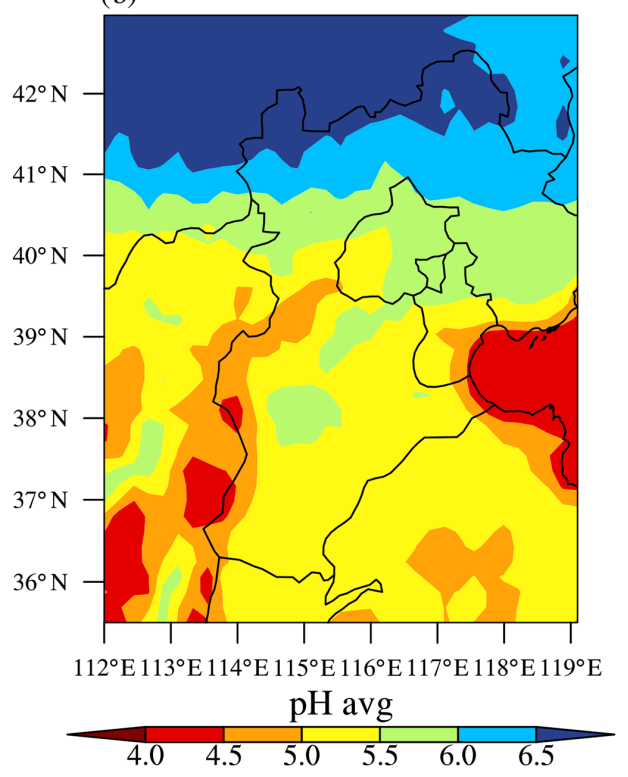

(d)

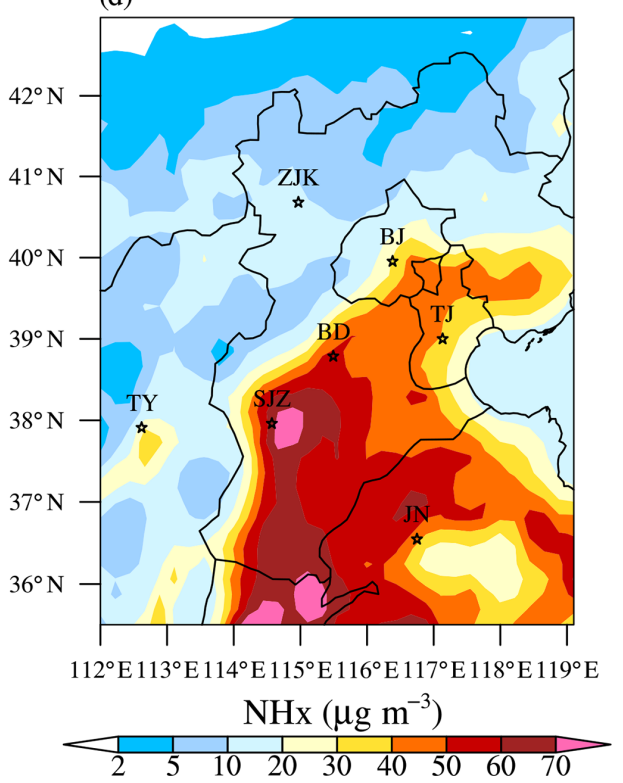

Figure 5. Fine particle $\mathrm{pH}$ and $\mathrm{NH}_{x}$ concentrations at the surface layer simulated in the CTRL scenario during January 2013. (a) The frequencies for different $\mathrm{pH}$ ranges. The radius $R$ for the pie chart is scaled using $R / R_{\text {ref }}=2 \exp (\log 10(\mathrm{AWC} / \mathrm{AWC}$ ref $))$, and the reference radius $R_{\text {ref }}$ and aerosol liquid water content $\left(\mathrm{AWC}_{\text {ref }}\right)$ are also shown. (b) The horizontal distribution of the average, (c) standard deviation for $\mathrm{pH}$, and (d) the concentrations of $\mathrm{NH}_{x}$. The locations for the seven cities of Beijing (BJ), Tianjin (TJ), Zhangjiakou (ZJK), Baoding (BD), Shijiazhuang (SJZ), Taiyuan (TY), and Jinan (JN) are also shown.

sions were considerably lower than less industrialized areas due to the titration effects of NO.

Figure $8 \mathrm{~b}$ shows the vertical profile of sulfate production rates averaged over the four dominant sulfate formation regimes at the surface layer (i.e., $\mathrm{O}_{3}, \mathrm{NO}_{2}, \mathrm{TMI}$, and $\mathrm{H}_{2} \mathrm{O}_{2}$; shown in Fig. 8a). Consistent with the surface layer, the vertical regime transition of sulfate formation was highly dependent on the vertical distribution of $\mathrm{pH}$ and oxidants and cata- lysts (Fig. 8c-f). Both $\mathrm{O}_{3}$ and TMI pathways played the dominant role at higher altitudes between 0.5 and $2.0 \mathrm{~km}$ a.g.1. (Fig. 8b). Interestingly, the vertical profile pattern for $\mathrm{pH}$ potentially enhanced the TMI pathway but hindered the $\mathrm{O}_{3}$ pathway, while the vertical profile pattern for concentrations of oxidants and catalysts disfavored the TMI pathway but favored the $\mathrm{O}_{3}$ pathway. As shown in Fig. 8b, the relative contributions of the $\mathrm{NO}_{2}$ pathway rapidly decreased with 

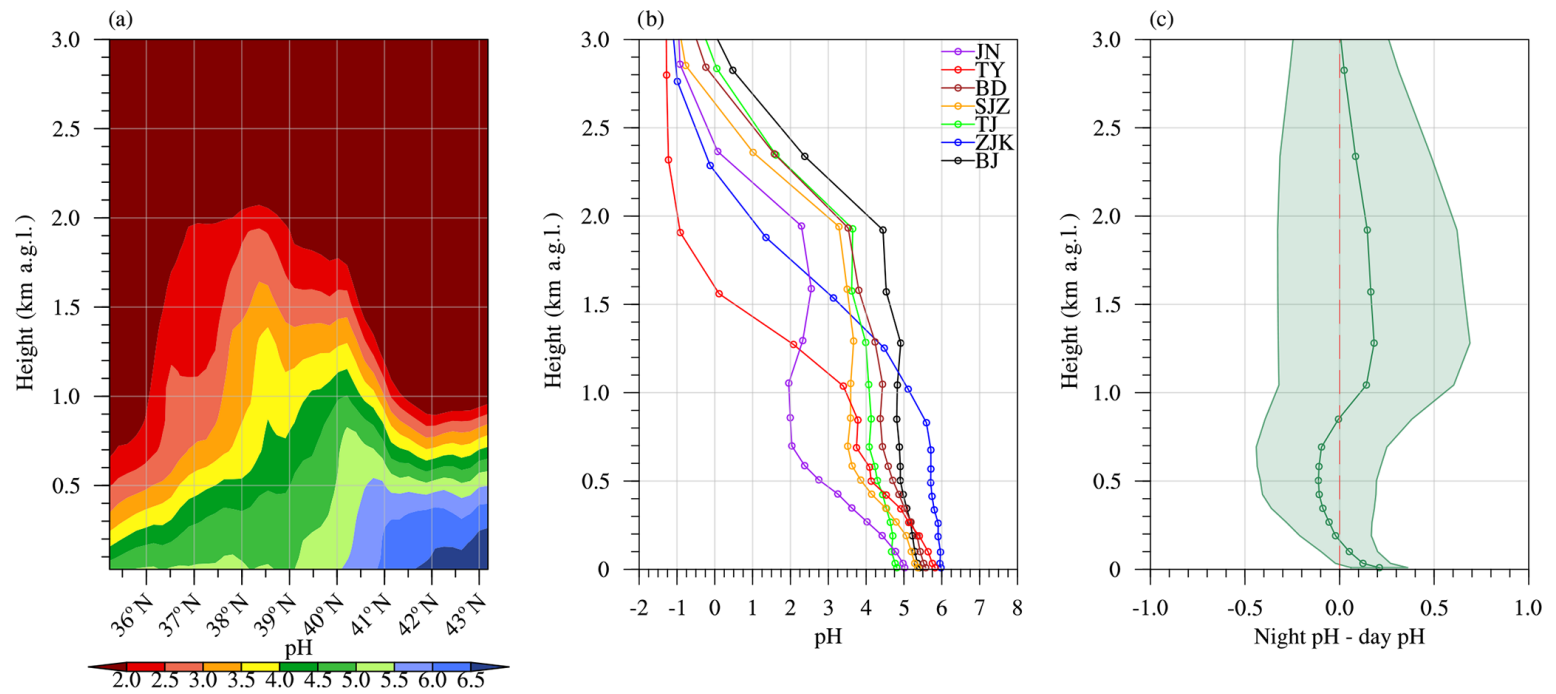

Figure 6. (a) Latitude-height cross section for the monthly mean fine particle $\mathrm{pH}$ averaged between 113 and $119^{\circ} \mathrm{E}$, (b) vertical profile for the monthly mean fine particle $\mathrm{pH}$ over the seven cities of Beijing (BJ), Tianjin (TJ), Zhangjiakou (ZJK), Baoding (BD), Shijiazhuang (SJZ), Taiyuan (TY), and Jinan (JN) (locations shown in Fig. 5c), and (c) vertical profile for the monthly mean day-night difference of pH (standard deviation is shown as shading) for the domain-wide grid cells in the CTRL scenario during January 2013.

(b)

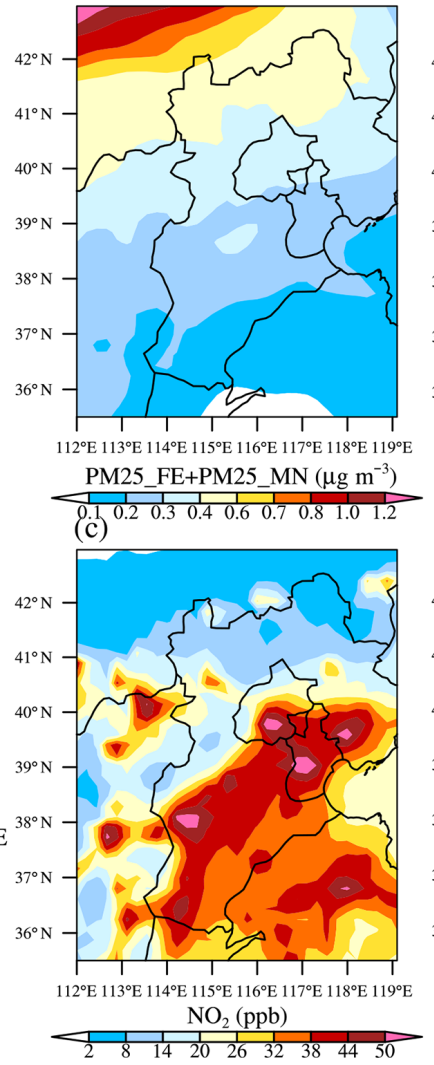

(d)

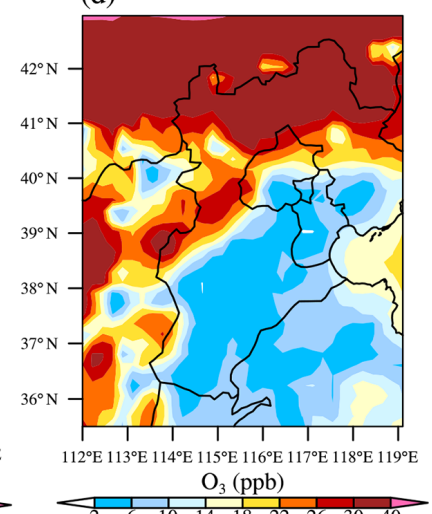

(e)

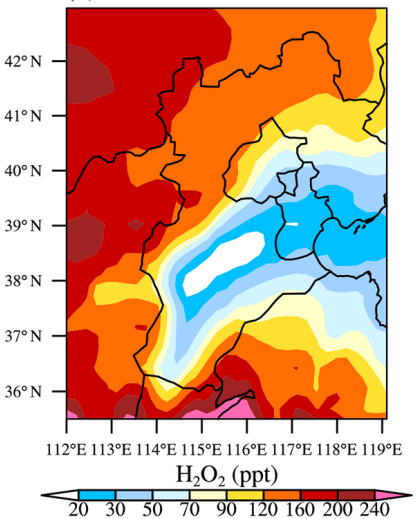

Figure 7. (a) The relative contributions of six sulfate formation pathways, namely aqueous-phase oxidation by dissolved $\mathrm{O}_{3}, \mathrm{H}_{2} \mathrm{O}_{2}$, TMI (in presence of $\mathrm{O}_{2}$ ), $\mathrm{NO}_{2}$, and $\mathrm{CH}_{3} \mathrm{OOH}$, as well as gas-particle partitioning of $\mathrm{H}_{2} \mathrm{SO}_{4}$ vapor (GPP) at the surface layer simulated in the CTRL scenario during January 2013. The radius $R$ for the pie chart in (a) is scaled using $R / R_{\text {ref }}=2 \exp \left(\log 10\left(P / P_{\text {ref }}\right)\right)$, and the reference sulfate production rate $P$ is also shown. Horizontal distribution of the concentrations of (b) the sum of PM25_FE and PM25_MN, (c) $\mathrm{NO}_{2}$, (d) $\mathrm{O}_{3}$, and $(\mathbf{e}) \mathrm{H}_{2} \mathrm{O}_{2}$ simulated in the CTRL scenario during January 2013. 
increasing altitude, which is consistent with the decreasing trend in both $\mathrm{NO}_{2}$ concentrations (Fig. 8f) and aerosol pH. The $\mathrm{H}_{2} \mathrm{O}_{2}$ pathway was non-negligible only in the lower boundary layer over the $\mathrm{H}_{2} \mathrm{O}_{2}$ regime and $\mathrm{NO}_{2}$ regime. The GPP pathway tended to become more important with increasing altitude mainly due to the decreasing trend in aerosol water content. At higher altitudes above $\sim 3 \mathrm{~km}$ a.g.l., aqueousphase oxidation in aerosol water became negligible.

Compared to nitrate, aqueous-phase oxidation was more important to sulfate formation in the North China Plain. For example, according to our simulation, over the Beijing site, below $\sim 2 \mathrm{~km}$ a.g.l., aqueous-phase oxidation in aerosol water accounted for $\sim 100 \%$ and $80 \%-90 \%$ of SO $4^{\mathrm{T}}$ formation during nighttime and daytime, respectively. While, its respective contributions to nighttime and daytime $\mathrm{NO}^{\mathrm{T}}$ formation were only $40 \%-70 \%$ and $0 \%-10 \%$.

\subsection{Discussion}

The uncertainties of predicted $\mathrm{pH}$ and sulfate formation relevant to the adjusted emission parameters (for $\mathrm{NH}_{3}$, crustal minerals, $\mathrm{Fe}^{3+} / \mathrm{Mn}^{2+}$ ions, and chlorides) and assumed phase state are further investigated. We focus on four aspects, namely surface layer $\mathrm{pH}$ (denoted as $\mathrm{pH}_{\text {surf }}$ ) and its

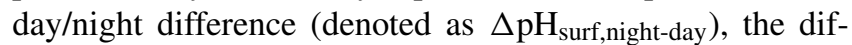
ference between surface layer $\mathrm{pH}$ and $\mathrm{pH}$ at $\sim 2 \mathrm{~km}$ a.g.l. (denoted as $\Delta \mathrm{pH}_{\text {surf- } 2 \mathrm{~km}}$ ), and surface layer sulfate production rates (denoted as $P_{\mathrm{S}(\mathrm{VI}) \text {,surf }}$ ) through different pathways for the domain-wide grid cells south of $41^{\circ} \mathrm{N}$. As shown in Fig. 9, different scenarios predict different $\mathrm{pH}_{\text {surf }}$ and $P_{\mathrm{S}(\mathrm{VI}) \text {,surf }}$; nonetheless, $\Delta \mathrm{pH}_{\text {surf,night-day }}$ and $\Delta \mathrm{pH}_{\text {surf- } 2 \mathrm{~km}}$ are approximately 0.2 and 5.0, respectively, for almost all the sensitivity tests, indicating that the diurnal cycle pattern at the surface layer and the altitudinal decrease in $\mathrm{pH}$ will be robust.

We first examine the sensitivities of our results to $\mathrm{NH}_{3}$ and crustal minerals. When $\mathrm{NH}_{3}$ emissions are completely removed (A0 scenario), a strong acidic aerosol phase is predicted (mean $\mathrm{pH}_{\text {surf }} \sim 0$ ), while the $P_{\mathrm{S}(\mathrm{VI}) \text {,surf }}$ decreases by $\sim 60 \%$ as in the CTRL scenario (due to lack of efficient water-absorbing ammoniates). If PM25_OCAT emissions are removed or halved (OCAT0 and OCAT0.5 scenarios), the averaged $\mathrm{pH}$ decreases to 4.2 and 4.6, respectively,

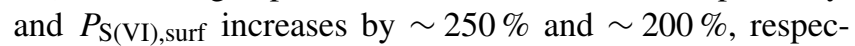
tively, compared to the CTRL scenario (a lower $\mathrm{pH}$ favors sulfate production through the TMI pathway). Doubling both $\mathrm{NH}_{3}$ and PM25_OCAT emissions (A2 and OCAT2 scenarios) leads to a slightly higher $\mathrm{pH}_{\text {surf }}$ and a similar $P_{\mathrm{S}(\mathrm{VI}) \text { surf }}$, with the sulfate formation dominated by $\mathrm{NO}_{2}$ and $\mathrm{O}_{3}$ pathways. For the control experiments of MEIC_CTRL (using the original MEIC inventory), predicted $\mathrm{pH}_{\text {surf }}$ is lower, and the relative contribution to sulfate formation is decreased for the $\mathrm{NO}_{2}$ pathway but increased for the TMI pathway. Interestingly, rapid production of sulfate could be maintained over a wide $\mathrm{pH}$ range $(\sim 4.2-5.7)$ with the varying emissions for
$\mathrm{NH}_{3}$ and crustal particles (transition between the dominant TMI pathway and dominant $\mathrm{NO}_{2} / \mathrm{O}_{3}$ pathway).

We have also investigated the effect of emissions of chlorides and $\mathrm{Fe}^{3+} / \mathrm{Mn}^{2+}$ ions. Removing all the chloride emissions (CL0 scenario) has a negligible effect on both aerosol $\mathrm{pH}$ and sulfate production. However, if the chloride emissions are doubled (CL2 scenario), $\mathrm{pH}$ slightly decreases to

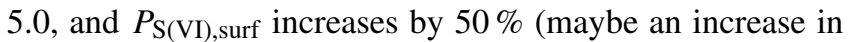
$\mathrm{NH}_{4} \mathrm{Cl}$ leading to an enhanced water absorption). When both $\mathrm{FS}_{\mathrm{FE} 3}+$ and $\mathrm{FS}_{\mathrm{MN} 2^{+}}$equal zero (the TMI0 scenario, and the TMI pathway is shut down), $P_{\mathrm{S}(\mathrm{VI}) \text {,surf }}$ decreases almost by half and $\mathrm{pH}_{\text {surf }}$ (5.5) is slightly higher. Interestingly, when both $\mathrm{FS}_{\mathrm{FE} 3^{+}}$and $\mathrm{FS}_{\mathrm{MN} 2^{+}}$are halved (TMI0.5 scenario), a similar $\mathrm{pH}_{\text {surf }}$ and $P_{\mathrm{S}(\mathrm{VI}) \text {,surf is predicted as in the TMI0 sce- }}$ nario. When both $\mathrm{FS}_{\mathrm{FE}} 3^{+}$and $\mathrm{FS}_{\mathrm{MN} 2}$ are doubled (TMI2

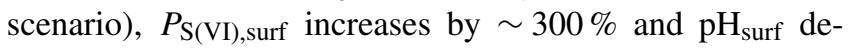
creases to 4.6. Our results indicate that sulfate production is rather sensitive to the availability of TMI species. Unfortunately, the concentrations, as well as sources, of TMI species in aerosol water during haze episodes remain not well constrained or understood. The simulated mean concentrations of $\mathrm{Fe}^{3+}$ and $\mathrm{Mn}^{2+}$ in $\mathrm{PM}_{2.5}$ at the Beijing TSU site are 3.2 and $3.6 \mathrm{ng} \mathrm{m}^{-3}$, respectively, and they are smaller than the observed concentrations of soluble Fe and Mn (1.5-16 and $10-41 \mathrm{ng} \mathrm{m}^{-3}$, respectively) in $\mathrm{PM}_{2.5}$ at a Xi'an site (Wang et al., 2016). Note that $\mathrm{Fe}^{3+} / \mathrm{Mn}^{2+}$ ions also have an anthropogenic source and were estimated to account for $10 \%-$ $30 \%$ of ions in Beijing (Shao et al., 2019). Furthermore, the soluble $\mathrm{Fe} / \mathrm{Mn}$ speciation (including $\mathrm{Fe}^{3+}-\mathrm{Fe}^{2+}$ and $\mathrm{Mn}^{2+}-$ $\mathrm{Mn}^{3+}-\mathrm{Mn}^{4+}$ cycling) depends on dust mineralogy, particle acidity, and heterogeneous redox reactions (Takahashi et al., 2011; Schroth et al., 2009), and it is very difficult to be explicitly treated. The activity coefficients for $\mathrm{Fe}^{3+} / \mathrm{Mn}^{2+}$ ions under the high ionic strength environment might also differ (Cheng et al., 2016). The treatment of the TMI pathway should be further improved in future studies.

Different phase state assumptions predict slightly different $\mathrm{pH}_{\text {surf }}$ but distinct sulfate production. Compared with CTRL scenario, assuming a fixed metastable phase state (MSTB scenario) predicts a slightly lower $\mathrm{pH}_{\text {surf }}(5.0)$ and $40 \%$ higher $P_{\mathrm{S}(\mathrm{VI}) \text {,surf }}$, and the contribution of the TMI pathway increases. Assuming a fixed stable phase state predicts a slightly higher $\mathrm{pH}$ (5.3) and $25 \%$ lower $P_{\mathrm{S}(\mathrm{VI}) \text {,surf (maybe }}$ mainly due to the changes in predicted aerosol water content), and the contribution of the $\mathrm{NO}_{2}$ pathway increases. Previous box model studies reported a similar finding regarding the minor impacts of phase state assumption on $\mathrm{pH}$ (Song et al., 2018).

\section{Conclusions}

The focus of the current study is to investigate the spatiotemporal variabilities of aerosol $\mathrm{pH}$ and regime transitions of sulfate formation at a regional scale. For this purpose, an aerosol 

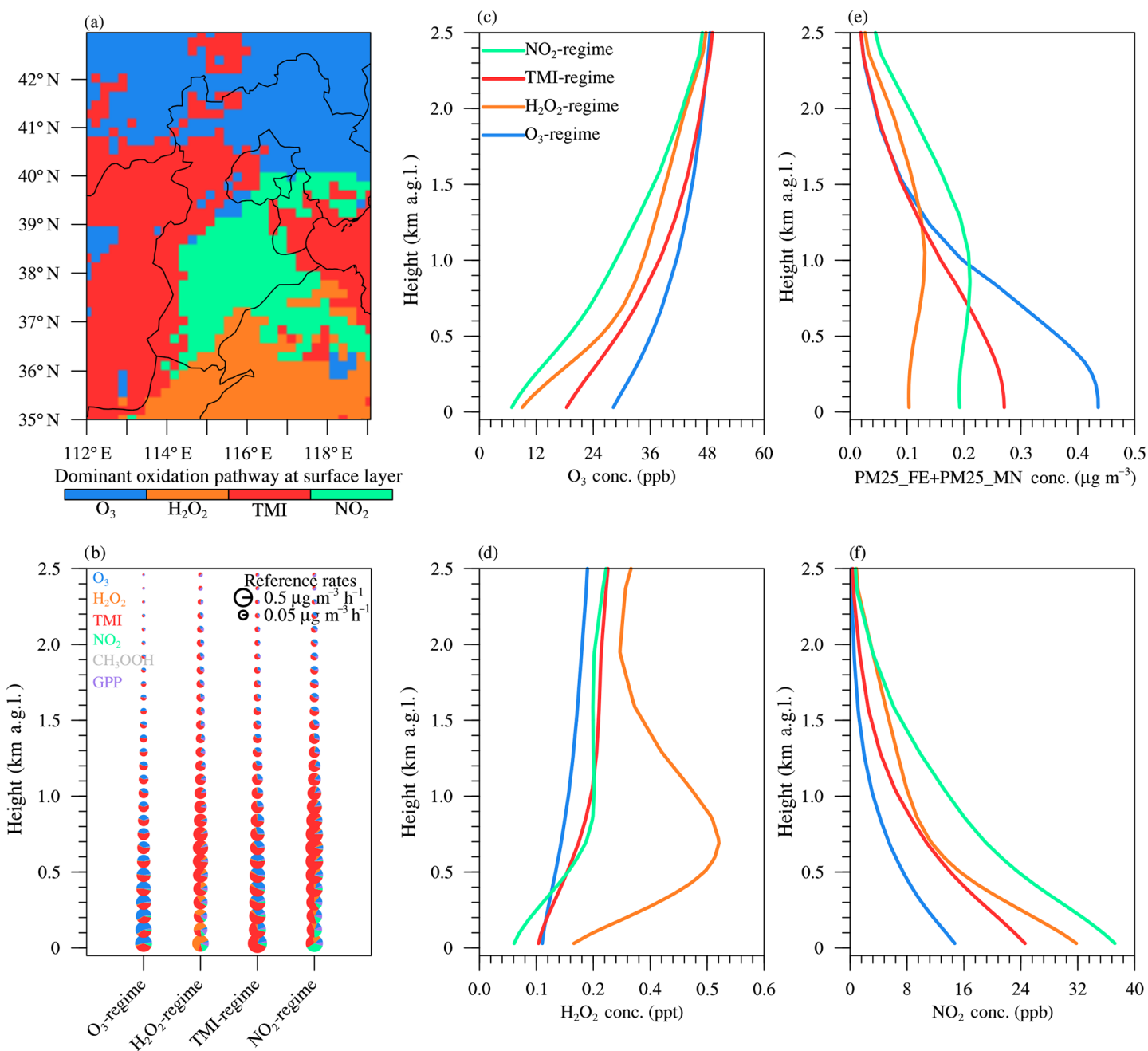

Figure 8. Dominant sulfate formation pathway at the surface layer (a) and the vertical profile of sulfate production through different pathways (b), as well as concentrations of the oxidants of $\mathrm{O}_{3}(\mathbf{c}), \mathrm{H}_{2} \mathrm{O}_{2}$ (d), TMI (e), and $\mathrm{NO}_{2}$ (f) averaged over the four dominant oxidation regimes $\left(\mathrm{O}_{3}, \mathrm{H}_{2} \mathrm{O}_{2}\right.$, TMI, and $\mathrm{NO}_{2}$, respectively, as shown in Fig. 8a) and simulated in the CTRL scenario during January 2013. Contributions from different sulfate formation pathways are also shown in pie charts, and the radius $R$ for the pie chart is scaled depending on the sulfate production rate $P$ using $R / R_{\text {ref }}=2 \exp \left(\log 10\left(P / P_{\text {ref }}\right)\right)$.

water chemistry (AWAC) module for sulfate and nitrate formation in aerosol water was developed and implemented using the results (including aerosol water and $\mathrm{pH}$ ) of the revised ISORROPIA II model as input data. With this improved version of Weather Research Forecasting Model with Chemistry (WRF-Chem), we simulated the severe and successive haze pollution spreading over the North China Plain during January 2013. Control experiments could reproduce well the observed inorganic components of fine particles (including sulfate, nitrate, ammonium, chloride, sodium, and crustal minerals), as well as $\mathrm{SO}_{2}, \mathrm{NO}_{2}, \mathrm{O}_{3}$, and relative humidity, compared to the observations at the Beijing Tsinghua University site. Impacts of the uncertainties in parameters and assumptions have also been discussed.

The vertical profile and diurnal cycle pattern for aerosol $\mathrm{pH}$ were closely associated with the spatiotemporal variation in the abundance of acidic and alkaline fine particle components and their gaseous counterparts. The competition between the ammonia, crustal particles, and acidic components (such as sulfate and nitrate) could play an important role in determining $\mathrm{pH}$ in different vertical layers. The monthly mean $\mathrm{pH}$ at the surface layer exhibited a large spatial variability over the North China Plain. Mean $\mathrm{pH}$ was greater than 6 for the areas with higher latitudes north of $41^{\circ} \mathrm{N}$ (mainly influenced by the abundant crustal particles) and was mostly between 4.4 and 5.7 (10\% and $90 \%$ quantiles, respectively) for vast areas south of $\sim 41^{\circ} \mathrm{N}$ (with $\mathrm{NH}_{x}$ as the driving factor) over the North China Plain. The trend that aerosol acidity was enhanced with increasing altitude was consistent for all latitudes $\left(35-43^{\circ} \mathrm{N}\right)$ investigated, while the vertical gradients of $\mathrm{pH}$ varied between different locations. The diurnal cycle 


\begin{tabular}{|c|c|c|c|c|c|c|c|c|c|c|}
\hline Scenarios & $\mathrm{pH}_{\text {surf }}$ & $\Delta \mathrm{pH}_{\text {surf,night-day }}$ & $\Delta \mathrm{pH}_{\text {surf-2km }}$ & $\mathrm{P}_{\mathrm{S}(\mathrm{VI}) \text {,surf }}$ & Domain-wide & $\begin{array}{l}\mathrm{O}_{3} \\
\text { regime }\end{array}$ & $\begin{array}{l}\mathrm{H}_{2} \mathrm{O}_{2} \\
\text { regime }\end{array}$ & $\begin{array}{l}\text { TMI } \\
\text { regime }\end{array}$ & $\begin{array}{l}\mathrm{NO}_{2} \\
\text { regime }\end{array}$ & \\
\hline CTRL & $5.2 \pm 0.5$ & $0.2 \pm 0.2$ & $5.1 \pm 1.1$ & $0.8 \pm 0.8$ & & & & & & Pathways \\
\hline MEIC_CTRL & $4.5 \pm 0.7$ & $0.2 \pm 0.2$ & $4.7 \pm 1.1$ & $0.6 \pm 0.5$ & & & & & & $\mathrm{H}_{2} \mathrm{O}_{2}$ \\
\hline $\mathrm{A} 0$ & $0.1 \pm 0.6$ & $0.0 \pm 0.2$ & $0.6 \pm 1.0$ & $0.3 \pm 0.3$ & & & $\theta$ & & & $\begin{array}{l}\text { TMI } \\
\mathrm{NO}_{2}\end{array}$ \\
\hline A2 & $5.7 \pm 0.4$ & $0.2 \pm 0.1$ & $5.2 \pm 1.3$ & $0.6 \pm 0.5$ & & & & & & $\begin{array}{l}\mathrm{CH}_{3} \mathrm{OOH} \\
\mathrm{GPP}\end{array}$ \\
\hline OCAT0 & $4.2 \pm 0.9$ & $0.3 \pm 0.2$ & $5.4 \pm 0.9$ & $2.0 \pm 2.3$ & & & & & & \\
\hline OCAT0.5 & $4.6 \pm 0.7$ & $0.3 \pm 0.2$ & $5.1 \pm 0.9$ & $1.7 \pm 1.9$ & & & & & & \\
\hline OCAT2 & $5.4 \pm 0.5$ & $0.2 \pm 0.2$ & $4.8 \pm 1.4$ & $0.7 \pm 0.5$ & & & & & & Reference $P_{S(V I), \text { surf }}$ \\
\hline TMIO & $5.4 \pm 0.5$ & $0.2 \pm 0.1$ & $5.2 \pm 1.2$ & $0.4 \pm 0.3$ & & & & & & $\bigoplus 0.5 \mu \mathrm{g} \mathrm{m}^{-3} \mathrm{~h}^{-1}$ \\
\hline TMI0.5 & $5.4 \pm 0.6$ & $0.2 \pm 0.2$ & $5.5 \pm 1.0$ & $0.5 \pm 0.4$ & & & & & & $\Theta \quad 0.1 \mu \mathrm{g} \mathrm{m}{ }^{-3} \mathrm{~h}^{-1}$ \\
\hline TMI2 & $4.6 \pm 0.7$ & $0.2 \pm 0.2$ & $4.6 \pm 1.1$ & $2.2 \pm 2.6$ & & & & & & \\
\hline CLO & $5.1 \pm 0.5$ & $0.2 \pm 0.1$ & $5.0 \pm 1.0$ & $0.7 \pm 0.8$ & & & & & & \\
\hline CL2 & $5.0 \pm 0.6$ & $0.2 \pm 0.2$ & $4.9 \pm 1.1$ & $1.1 \pm 1.2$ & & & & & & \\
\hline MSTB & $5.0 \pm 0.6$ & $0.2 \pm 0.2$ & $4.6 \pm 1.0$ & $1.1 \pm 1.3$ & & & & & & \\
\hline STB & $5.3 \pm 0.6$ & $0.2 \pm 0.2$ & $5.6 \pm 1.1$ & $0.6 \pm 0.5$ & & & & & & \\
\hline
\end{tabular}

Figure 9. Surface layer $\mathrm{pH}$ (denoted as $\mathrm{pH}_{\text {surf }}$ ) and its day-night difference (denoted as $\Delta \mathrm{pH}_{\text {surf,night-day), the difference between surface }}$

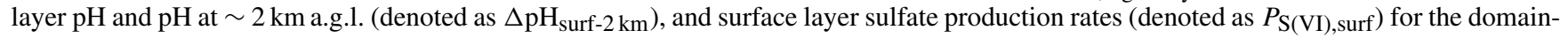
wide grid cells south of $41^{\circ} \mathrm{N}$ in the control and sensitivity experiments during January 2013. Contributions from different sulfate formation pathways over the domain-wide grid cells south of $41^{\circ} \mathrm{N}$ and the four dominant sulfate formation regimes $\left(\mathrm{O}_{3}, \mathrm{H}_{2} \mathrm{O}_{2}, \mathrm{TMI}\right.$ and $\mathrm{NO}_{2}$, respectively, as defined in Fig. 8a) are also shown in pie charts. The radius $R$ for the pie chart is scaled depending on the sulfate production rate $P$ using $R / R_{\text {ref }}=2 \exp \left(\log 10\left(P / P_{\text {ref }}\right)\right)$.

pattern existed only for the domain-wide cells in the lower boundary layer, in which nighttime $\mathrm{pH}$ was higher.

In the AWAC module, six sulfate formation pathways in aerosol water are implemented and compared, namely aqueous-phase oxidation by dissolved $\mathrm{O}_{3}, \mathrm{NO}_{2}, \mathrm{H}_{2} \mathrm{O}_{2}$, TMI (in the presence of $\mathrm{O}_{2}$ ) and $\mathrm{CH}_{3} \mathrm{OOH}$, as well as gas-particle partitioning of $\mathrm{H}_{2} \mathrm{SO}_{4}$ vapor (GPP). The relative contributions of different sulfate formation pathways in aerosol water depended on both $\mathrm{pH}$ and the concentrations of each oxidant/catalyst. At the surface layer, $\mathrm{O}_{3}, \mathrm{NO}_{2}$, TMI, and $\mathrm{H}_{2} \mathrm{O}_{2}$ pathways were the most important in different locations over the North China Plain, and four regions with three distinct regimes have been found. With the increasing height, $\mathrm{O}_{3}$, TMI, and GPP pathways became more important, while contributions from $\mathrm{NO}_{2}$ and $\mathrm{H}_{2} \mathrm{O}_{2}$ pathways decreased rapidly. At higher altitudes above $\sim 3 \mathrm{~km}$ above ground level, aqueous-phase oxidation in aerosol water became negligible.

The diurnal cycle pattern at the surface layer and altitudinal decrease of $\mathrm{pH}$ is consistent for all the sensitivity tests with varying adjusted emission parameters and phase state assumptions except when $\mathrm{NH}_{3}$ emissions are completely removed. The $\mathrm{pH}$ is sensitive to the alkalization effect of $\mathrm{NH}_{3}$ and crustal particles; furthermore, the rapid production of sulfate could be maintained over a wide $\mathrm{pH}$ range (e.g., 4.25.7) with the varying emissions for $\mathrm{NH}_{3}$ and crustal particles (transition from the dominant TMI pathway to the dominant $\mathrm{NO}_{2} / \mathrm{O}_{3}$ pathway). The sulfate production is rather sensi- tive to the concentrations of TMI species, and doubling the TMI species sources almost triples the sulfate production. Changes in chloride emissions and phase state assumptions both have a relatively minor effect on $\mathrm{pH}$, but sulfate formation could be changed as the predicted aerosol water changes. Our studies suggest that sources of crustal particles, $\mathrm{NH}_{3}$, and TMI species are very important factors for the aqueousphase chemistry during haze episodes and should be better constrained in future studies. Moreover, the use of a more detailed aqueous-phase mechanism involving the TMI species cycling and radical chain propagation is suggested. Uncertainties relevant to the algorithms to solve the aerosol thermodynamics, including the treatment of non-ideality, size effects, phase state, mixing state, the interactions between inorganic compounds and organic compounds, and phase separation, should also be addressed in future studies.

Data availability. The source code for the aerosol water chemistry module and the data used in this paper are available upon request from the corresponding authors Hang Su (h.su@mpic.de) or Yafang Cheng (yafang.cheng@mpic.de).

Supplement. The supplement related to this article is available online at: https://doi.org/10.5194/acp-20-11729-2020-supplement. 
Author contributions. HS and YC designed and led the study. WT developed the AWAC module and implemented the revised ISORROPIA II into WRF-Chem. WT performed model simulations. WT, HS, and YC analyzed data and interpreted the results. GZ supported the data analyses. JW, CW, and LL supported the modeling work. ML and QZ provided the MEIC for the year 2013. All coauthors have discussed the results and commented on the paper. WT wrote the paper with input from all coauthors.

Competing interests. The authors declare that they have no conflict of interest.

Acknowledgements. This study is supported by the Max Planck Society (MPG). Yafang Cheng would like to thank the Minerva program of the MPG.

Financial support. The article processing charges for this openaccess publication were covered by the Max Planck Society.

Review statement. This paper was edited by Veli-Matti Kerminen and reviewed by two anonymous referees.

\section{References}

Ackermann, I. J., Hass, H., Memmesheimer, M., Ebel, A., Binkowski, F. S., and Shankar, U.: Modal aerosol dynamics model for Europe: development and first applications, Atmos. Environ., 32, 2981-2999, https://doi.org/10.1016/S13522310(98)00006-5, 1998.

Baker, A. R., Jickells, T. D., Witt, M., and Linge, K. L.: Trends in the solubility of iron, aluminium, manganese and phosphorus in aerosol collected over the Atlantic Ocean, Mar. Chem., 98, 4358, https://doi.org/10.1016/j.marchem.2005.06.004, 2006.

Brimblecombe, P.: The Big Smoke (Routledge Revivals): A History of Air Pollution in London Since Medieval Times, Routledge, Abingdon, London, UK, 2012.

Chen, D., Liu, Z., Fast, J., and Ban, J.: Simulations of sulfatenitrate-ammonium (SNA) aerosols during the extreme haze events over northern China in October 2014, Atmos. Chem. Phys., 16, 10707-10724, https://doi.org/10.5194/acp-16-107072016, 2016.

Chen, T., Chu, B., Ge, Y., Zhang, S., Ma, Q., He, H., and Li, S. M.: Enhancement of aqueous sulfate formation by the coexistence of $\mathrm{NO} 2 / \mathrm{NH} 3$ under high ionic strengths in aerosol water, Environ. Pollut., 252, 236-244, https://doi.org/10.1016/j.envpol.2019.05.119, 2019.

Cheng, Y., Zheng, G., Wei, C., Mu, Q., Zheng, B., Wang, Z., Gao, M., Zhang, Q., He, K., Carmichael, G., Pöschl, U., and Su, H.: Reactive nitrogen chemistry in aerosol water as a source of sulfate during haze events in China, Sci. Adv., 2, e1601530, https://doi.org/10.1126/sciadv.1601530, 2016.
Claquin, T., Schulz, M., and Balkanski, Y. J.: Modeling the mineralogy of atmospheric dust sources, J. Geophys. Res.-Atmos., 104, 22243-22256, https://doi.org/10.1029/1999jd900416, 1999.

Clifton, C. L., Altstein, N., and Huie, R. E.: Rate constant for the reaction of nitrogen dioxide with sulfur(IV) over the $\mathrm{pH}$ range 5.3-13, Environ. Sci. Technol., 22, 586-589, https://doi.org/10.1021/es00170a018, 1988.

Damian, V., Sandu, A., Damian, M., Potra, F., and Carmichael, G. R.: The kinetic preprocessor KPP - a software environment for solving chemical kinetics, Comput. Chem. Eng., 26, 1567-1579, https://doi.org/10.1016/S0098-1354(02)00128-X, 2002.

Ding, J., Zhao, P., Su, J., Dong, Q., Du, X., and Zhang, Y.: Aerosol $\mathrm{pH}$ and its driving factors in Beijing, Atmos. Chem. Phys., 19, 7939-7954, https://doi.org/10.5194/acp-19-7939-2019, 2019.

Dong, X., Fu, J. S., Huang, K., Tong, D., and Zhuang, G.: Model development of dust emission and heterogeneous chemistry within the Community Multiscale Air Quality modeling system and its application over East Asia, Atmos. Chem. Phys., 16, 8157-8180, https://doi.org/10.5194/acp-16-8157-2016, 2016.

Dufour, G., Eremenko, M., Orphal, J., and Flaud, J.-M.: IASI observations of seasonal and day-to-day variations of tropospheric ozone over three highly populated areas of China: Beijing, Shanghai, and Hong Kong, Atmos. Chem. Phys., 10, 3787 3801, https://doi.org/10.5194/acp-10-3787-2010, 2010.

Duvall, R. M., Majestic, B. J., Shafer, M. M., Chuang, P. Y., Simoneit, B. R. T., and Schauer, J. J.: The water-soluble fraction of carbon, sulfur, and crustal elements in Asian aerosols and Asian soils, Atmos. Environ., 42, 5872-5884, https://doi.org/10.1016/j.atmosenv.2008.03.028, 2008.

Fountoukis, C. and Nenes, A.: ISORROPIA II: a computationally efficient thermodynamic equilibrium model for $\mathrm{K}^{+}$ $\mathrm{Ca}^{2+}-\mathrm{Mg}^{2+}-\mathrm{NH}_{4}^{+}-\mathrm{Na}^{+}-\mathrm{SO}_{4}^{2-}-\mathrm{NO}_{3}^{-}-\mathrm{Cl}^{-}-\mathrm{H}_{2} \mathrm{O}$ aerosols, Atmos. Chem. Phys., 7, 4639-4659, https://doi.org/10.5194/acp-74639-2007, 2007.

Gen, M. S., Zhang, R. F., Huang, D. D., Li, Y. J., and Chan, C. K.: Heterogeneous oxidation of $\mathrm{SO}_{2}$ in sulfate production during nitrate photolysis at $300 \mathrm{~nm}$ : effect of $\mathrm{pH}$, relative humidity, irradiation intensity, and the presence of organic compounds, Environ. Sci. Technol., 53, 8757-8766, https://doi.org/10.1021/acs.est.9b01623, 2019.

Ginoux, P., Chin, M., Tegen, I., Prospero, J. M., Holben, B., Dubovik, O., and Lin, S. J.: Sources and distributions of dust aerosols simulated with the GOCART model, J. Geophys. Res.-Atmos., 106, 20255-20273, https://doi.org/10.1029/2000jd000053, 2001.

Grell, G. A., Peckham, S. E., Schmitz, R., McKeen, S. A., Frost, G., Skamarock, W. C., and Eder, B.: Fully coupled "online" chemistry within the WRF model, Atmos. Environ., 39, 6957-6975, https://doi.org/10.1016/j.atmosenv.2005.04.027, 2005.

Guenther, A., Karl, T., Harley, P., Wiedinmyer, C., Palmer, P. I., and Geron, C.: Estimates of global terrestrial isoprene emissions using MEGAN (Model of Emissions of Gases and Aerosols from Nature), Atmos. Chem. Phys., 6, 3181-3210, https://doi.org/10.5194/acp-6-3181-2006, 2006.

Guo, H., Sullivan, A. P., Campuzano-Jost, P., Schroder, J. C., LopezHilfiker, F. D., Dibb, J. E., Jimenez, J. L., Thornton, J. A., Brown, S. S., Nenes, A., and Weber, R. J.: Fine particle pH and the partitioning of nitric acid during winter in the northeast- 
ern United States, J. Geophys. Res.-Atmos., 121, 10355-10376, https://doi.org/10.1002/2016jd025311, 2016.

Hsu, S. C., Wong, G. T. F., Gong, G. C., Shiah, F. K., Huang, Y. T., Kao, S. J., Tsai, F. J., Lung, S. C. C., Lin, F. J., Lin, I. I., Hung, C. C., and Tseng, C. M.: Sources, solubility, and dry deposition of aerosol trace elements over the East China Sea, Mar. Chem., 120, 116-127, https://doi.org/10.1016/j.marchem.2008.10.003, 2010.

Huang, J., Minnis, P., Chen, B., Huang, Z., Liu, Z., Zhao, Q., Yi, Y., and Ayers, J. K.: Long-range transport and vertical structure of Asian dust from CALIPSO and surface measurements during PACDEX, J. Geophys. Res.-Atmos., 113, D23212, https://doi.org/10.1029/2008JD010620, 2008.

Ibusuki, T. and Takeuchi, K.: Sulfur-dioxide oxidation by oxygen catalyzed by mixtures of manganese(Ii) and iron(Iii) in aqueoussolutions at environmental reaction conditions, Atmos. Environ., 21, 1555-1560, https://doi.org/10.1016/0004-6981(87)90317-9, 1987.

Jacob, D. J. and Brasseur, G. P.: Formulations of Radiative, Chemical, and Aerosol Rates, in: Modeling of Atmospheric Chemistry, Cambridge University Press, Cambridge, 205-252, 2017.

Johnson, M. S., Meskhidze, N., Solmon, F., Gasso, S., Chuang, P. Y., Gaiero, D. M., Yantosca, R. M., Wu, S. L., Wang, Y. X., and Carouge, C.: Modeling dust and soluble iron deposition to the South Atlantic Ocean, J. Geophys. Res.-Atmos., 115, D15202, https://doi.org/10.1029/2009jd013311, 2010.

Journet, E., Desboeufs, K. V., Caquineau, S., and Colin, J. L.: Mineralogy as a critical factor of dust iron solubility, Geophys. Res. Lett., 35, L07805 https://doi.org/10.1029/2007g1031589, 2008.

Kong, L., Tang, X., Zhu, J., Wang, Z., Pan, Y., Wu, H., Wu, L., Wu, Q., He, Y., and Tian, S.: Improved inversion of monthly ammonia emissions in China in combination of the Chinese Ammonia Monitoring Network and ensemble Kalman filter, Environ. Sci. Technol., 53, 12529-12538, https://doi.org/10.1021/acs.est.9b02701, 2019.

Kong, X., Forkel, R., Sokhi, R. S., Suppan, P., Baklanov, A., Gauss, M., Brunner, D., Barò, R., Balzarini, A., Chemel, C., Curci, G., Jiménez-Guerrero, P., Hirtl, M., Honzak, L., Im, U., Pérez, J. L., Pirovano, G., San Jose, R., Schlünzen, K. H., Tsegas, G., Tuccella, P., Werhahn, J., Žabkar, R., and Galmarini, S.: Analysis of meteorology-chemistry interactions during air pollution episodes using online coupled models within AQMEII phase-2, Atmos. Environ., 115, 527-540, https://doi.org/10.1016/j.atmosenv.2014.09.020, 2015.

Lee, Y. N. and Schwartz, S. E.: Precipitation Scavenging, in: Dry Deposition and Resuspension, Elsevier, New York, USA, 453470, 1983.

Lei, Y., Zhang, Q., He, K. B., and Streets, D. G.: Primary anthropogenic aerosol emission trends for China, 1990-2005, Atmos. Chem. Phys., 11, 931-954, https://doi.org/10.5194/acp-11-9312011, 2011.

Li, M., Zhang, Q., Streets, D. G., He, K. B., Cheng, Y. F., Emmons, L. K., Huo, H., Kang, S. C., Lu, Z., Shao, M., Su, H., Yu, X., and Zhang, Y.: Mapping Asian anthropogenic emissions of non-methane volatile organic compounds to multiple chemical mechanisms, Atmos. Chem. Phys., 14, 5617-5638, https://doi.org/10.5194/acp-14-5617-2014, 2014.

Li, G., Bei, N., Cao, J., Huang, R., Wu, J., Feng, T., Wang, Y., Liu, S., Zhang, Q., Tie, X., and Molina, L. T.: A possible pathway for rapid growth of sulfate during haze days in China, At- mos. Chem. Phys., 17, 3301-3316, https://doi.org/10.5194/acp17-3301-2017, 2017a.

Li, M., Zhang, Q., Kurokawa, J.-I., Woo, J.-H., He, K., Lu, Z., Ohara, T., Song, Y., Streets, D. G., Carmichael, G. R., Cheng, Y., Hong, C., Huo, H., Jiang, X., Kang, S., Liu, F., Su, H., and Zheng, B.: MIX: a mosaic Asian anthropogenic emission inventory under the international collaboration framework of the MICS-Asia and HTAP, Atmos. Chem. Phys., 17, 935-963, https://doi.org/10.5194/acp-17-935-2017, 2017b.

Liu, M. X., Song, Y., Zhou, T., Xu, Z. Y., Yan, C. Q., Zheng, M., Wu, Z. J., Hu, M., Wu, Y. S., and Zhu, T.: Fine particle pH during severe haze episodes in northern China, Geophys. Res. Lett., 44, 5213-5221, https://doi.org/10.1002/2017g1073210, 2017.

Liu, Y., Bourgeois, A., Warner, T., Swerdlin, S., and Hacker, J.: Implementation of observation-nudging based FDDA into WRF for supporting ATEC test operations, WRF/MM5 Users' Workshop, NCAR, Boulder, Colorado, USA, June 2005, 27-30, 2005.

Liu, Y., Fan, Q., Chen, X., Zhao, J., Ling, Z., Hong, Y., Li, W., Chen, X., Wang, M., and Wei, X.: Modeling the impact of chlorine emissions from coal combustion and prescribed waste incineration on tropospheric ozone formation in China, Atmos. Chem. Phys., 18, 2709-2724, https://doi.org/10.5194/acp-182709-2018, 2018.

Madronich, S.: Photodissociation in the atmosphere: 1. actinic flux and the effects of ground reflections and clouds, J. Geophys. Res.-Atmos., 92, 9740-9752, https://doi.org/10.1029/JD092iD08p09740, 1987.

Makar, P. A., Gong, W., Hogrefe, C., Zhang, Y., Curci, G., Zabkar, R., Milbrandt, J., Im, U., Balzarini, A., Baro, R., Bianconi, R., Cheung, P., Forkel, R., Gravel, S., Hirtl, M., Honzak, L., Hou, A., Jimenez-Guerrero, P., Langer, M., Moran, M. D., Pabla, B., Perez, J. L., Pirovano, G., San Jose, R., Tuccella, P., Werhahn, J., Zhang, J., and Galmarini, S.: Feedbacks between air pollution and weather, part 2: Effects on chemistry, Atmos. Environ., 115, 499-526, https://doi.org/10.1016/j.atmosenv.2014.10.021, 2015.

Meng, Z. Y., Lin, W. L., Jiang, X. M., Yan, P., Wang, Y., Zhang, Y. M., Jia, X. F., and Yu, X. L.: Characteristics of atmospheric ammonia over Beijing, China, Atmos. Chem. Phys., 11, 61396151, https://doi.org/10.5194/acp-11-6139-2011, 2011.

Meskhidze, N., Chameides, W., Nenes, A., and Chen, G.: Iron mobilization in mineral dust: Can anthropogenic $\mathrm{SO}_{2}$ emissions affect ocean productivity?, Geophys. Res. Lett., 30, 2085, https://doi.org/10.1029/2003GL018035, 2003.

Moch, J. M., Dovrou, E., Mickley, L. J., Keutsch, F. N., Cheng, Y., Jacob, D. J., Jiang, J. K., Li, M., Munger, J. W., Qiao, X. H., and Zhang, Q.: Contribution of hydroxymethane sulfonate to ambient particulate matter: a potential explanation for high particulate sulfur during severe winter haze in Beijing, Geophys. Res. Lett., 45, 11969-11979, https://doi.org/10.1029/2018gl079309, 2018.

Sandu, A., Verwer, J., Blom, J., Spee, E., Carmichael, G., and Potra, F.: Benchmarking stiff ODE solvers for atmospheric chemistry problems II: Rosenbrock solvers, Atmos. Environ., 31, 3459-3472, https://doi.org/https://doi.org/10.1016/S13522310(97)83212-8, 1997.

Sandu, A. and Sander, R.: Technical note: Simulating chemical systems in Fortran90 and Matlab with the Kinetic PreProcessor KPP-2.1, Atmos. Chem. Phys., 6, 187-195, https://doi.org/10.5194/acp-6-187-2006, 2006. 
Schell, B., Ackermann, I. J., Hass, H., Binkowski, F. S., and Ebel, A.: Modeling the formation of secondary organic aerosol within a comprehensive air quality model system, J. Geophys. Res.-Atmos., 106, 28275-28293, https://doi.org/10.1029/2001JD000384, 2001.

Schroth, A. W., Crusius, J., Sholkovitz, E. R., and Bostick, B. C.: Iron solubility driven by speciation in dust sources to the ocean, Nat. Geosci., 2, 337-340, https://doi.org/10.1038/Ngeo501, 2009.

Seinfeld, J. H. and Pandis, S. N.: Atmospheric chemistry and physics: from air pollution to climate change, John Wiley \& Sons, Hoboken, New Jersey, USA, 2016.

Shampine, L. F.: Implementation of Rosenbrock methods, ACM T. Math. Software, 8, 93-113, https://doi.org/10.1145/355993.355994, 1982.

Shao, J., Chen, Q., Wang, Y., Lu, X., He, P., Sun, Y., Shah, V., Martin, R. V., Philip, S., Song, S., Zhao, Y., Xie, Z., Zhang, L., and Alexander, B.: Heterogeneous sulfate aerosol formation mechanisms during wintertime Chinese haze events: air quality model assessment using observations of sulfate oxygen isotopes in Beijing, Atmos. Chem. Phys., 19, 6107-6123, https://doi.org/10.5194/acp-19-6107-2019, 2019.

Shi, G., Xu, J., Peng, X., Xiao, Z., Chen, K., Tian, Y., Guan, X., Feng, Y., Yu, H., Nenes, A., and Russell, A. G.: pH of aerosols in a polluted atmosphere: source contributions to highly acidic aerosol, Environ. Sci. Technol., 51, 4289-4296, https://doi.org/10.1021/acs.est.6b05736, 2017.

Shi, Z. B., Krom, M. D., Jickells, T. D., Bonneville, S., Carslaw, K. S., Mihalopoulos, N., Baker, A. R., and Benning, L. G.: Impacts on iron solubility in the mineral dust by processes in the source region and the atmosphere: a review, Aeolian Res., 5, $21-$ 42, https://doi.org/10.1016/j.aeolia.2012.03.001, 2012.

Song, S., Gao, M., Xu, W., Shao, J., Shi, G., Wang, S., Wang, Y., Sun, Y., and McElroy, M. B.: Fine-particle $\mathrm{pH}$ for Beijing winter haze as inferred from different thermodynamic equilibrium models, Atmos. Chem. Phys., 18, 7423-7438, https://doi.org/10.5194/acp-18-7423-2018, 2018.

Song, S., Gao, M., Xu, W., Sun, Y., Worsnop, D. R., Jayne, J. T., Zhang, Y., Zhu, L., Li, M., Zhou, Z., Cheng, C., Lv, Y., Wang, Y., Peng, W., Xu, X., Lin, N., Wang, Y., Wang, S., Munger, J. W., Jacob, D. J., and McElroy, M. B.: Possible heterogeneous chemistry of hydroxymethanesulfonate (HMS) in northern China winter haze, Atmos. Chem. Phys., 19, 1357-1371, https://doi.org/10.5194/acp-19-1357-2019, 2019.

Stockwell, W. R., Middleton, P., Chang, J. S., and Tang, X.: The second generation regional acid deposition model chemical mechanism for regional air quality modeling, J. Geophys. Res.-Atmos., 95, 16343-16367, https://doi.org/10.1029/JD095iD10p16343, 1990.

Stockwell, W. R., Kirchner, F., Kuhn, M., and Seefeld, S.: A new mechanism for regional atmospheric chemistry modeling, J. Geophys. Res.-Atmos., 102, 25847-25879, https://doi.org/10.1029/97JD00849, 1997.

Su, H., Cheng, Y., and Po“schl, U.: New Multiphase Chemical Processes Influencing Atmospheric Aerosols, Air Quality, and Climate in the Anthropocene, Accounts Chem. Res., e1601530 1602983, https://doi.org/10.1021/acs.accounts.0c00246, 2020.

Sun, Y. L., Jiang, Q., Wang, Z. F., Fu, P. Q., Li, J., Yang, T., and Yin, Y.: Investigation of the sources and evolution processes of se- vere haze pollution in Beijing in January 2013, J. Geophys. Res.Atmos., 119, 4380-4398, https://doi.org/10.1002/2014jd021641, 2014.

Takahashi, Y., Higashi, M., Furukawa, T., and Mitsunobu, S.: Change of iron species and iron solubility in Asian dust during the long-range transport from western China to Japan, Atmos. Chem. Phys., 11, 11237-11252, https://doi.org/10.5194/acp-1111237-2011, 2011.

Tao, W., Liu, J., Ban-Weiss, G. A., Hauglustaine, D. A., Zhang, L., Zhang, Q., Cheng, Y., Yu, Y., and Tao, S.: Effects of urban land expansion on the regional meteorology and air quality of eastern China, Atmos. Chem. Phys., 15, 8597-8614, https://doi.org/10.5194/acp-15-8597-2015, 2015.

Tao, W., Liu, J., Ban-Weiss, G. A., Zhang, L., Zhang, J., Yi, K., and Tao, S.: Potential impacts of urban land expansion on Asian airborne pollutant outflows, J. Geophys. Res.-Atmos., 122, 76467663, https://doi.org/10.1002/2016JD025564, 2017.

Van Damme, M., Clarisse, L., Whitburn, S., Hadji-Lazaro, J., Hurtmans, D., Clerbaux, C., and Coheur, P. F.: Industrial and agricultural ammonia point sources exposed, Nature, 564, 99-103, https://doi.org/10.1038/s41586-018-0747-1, 2018.

Walcek, C. J., and Taylor, G. R.: A Theoretical Method for Computing Vertical Distributions of Acidity and Sulfate Production within Cumulus Clouds, J. Atmos. Sci., 43, 339-355, https://doi.org/10.1175/1520 0469(1986)043<0339:ATMFCV>2.0.CO;2, 1986.

Wang, G., Zhang, R., Gomez, M. E., Yang, L., Levy Zamora, M., Hu, M., Lin, Y., Peng, J., Guo, S., Meng, J., Li, J., Cheng, C., Hu, T., Ren, Y., Wang, Y., Gao, J., Cao, J., An, Z., Zhou, W., Li, G., Wang, J., Tian, P., Marrero-Ortiz, W., Secrest, J., Du, Z., Zheng, J., Shang, D., Zeng, L., Shao, M., Wang, W., Huang, Y., Wang, Y., Zhu, Y., Li, Y., Hu, J., Pan, B., Cai, L., Cheng, Y., Ji, Y., Zhang, F., Rosenfeld, D., Liss, P. S., Duce, R. A., Kolb, C. E., and Molina, M. J.: Persistent sulfate formation from London Fog to Chinese haze, P. Natl. Acad. Sci. USA, 113, 13630-13635, https://doi.org/10.1073/pnas.1616540113, 2016.

Wang, H., Zhang, D., Zhang, Y., Zhai, L., Yin, B., Zhou, F., Geng, Y., Pan, J., Luo, J., Gu, B., and Liu, H.: Ammonia emissions from paddy fields are underestimated in China, Environ. Pollut., 235 482-488, https://doi.org/10.1016/j.envpol.2017.12.103, 2018.

Wiedinmyer, C., Akagi, S. K., Yokelson, R. J., Emmons, L. K., AlSaadi, J. A., Orlando, J. J., and Soja, A. J.: The Fire INventory from NCAR (FINN): a high resolution global model to estimate the emissions from open burning, Geosci. Model Dev., 4, 625641, https://doi.org/10.5194/gmd-4-625-2011, 2011.

Wu, J., Bei, N., Hu, B., Liu, S., Zhou, M., Wang, Q., Li, X., Liu, L., Feng, T., Liu, Z., Wang, Y., Cao, J., Tie, X., Wang, J., Molina, L. T., and Li, G.: Is water vapor a key player of the wintertime haze in North China Plain?, Atmos. Chem. Phys., 19, 87218739, https://doi.org/10.5194/acp-19-8721-2019, 2019.

Xu, X., Lin, W., Wang, T., Yan, P., Tang, J., Meng, Z., and Wang, Y.: Long-term trend of surface ozone at a regional background station in eastern China 1991-2006: enhanced variability, Atmos. Chem. Phys., 8, 2595-2607, https://doi.org/10.5194/acp-8-25952008, 2008.

Xue, J., Yu, X., Yuan, Z. B., Griffith, S. M., Lau, A. K. H., Seinfeld, J. H., and Yu, J. Z.: Efficient control of atmospheric sulfate production based on three formation regimes, Nat. Geosci., 12, 977-982, https://doi.org/10.1038/s41561-019-0485-5, 2019. 
Zhang, Q., Streets, D. G., He, K., Wang, Y., Richter, A., Burrows, J. P., Uno, I., Jang, C. J., Chen, D., and Yao, Z.: NOx emission trends for China, 1995-2004: the view from the ground and the view from space, J. Geophys. Res.-Atmos., 112, D22306, https://doi.org/10.1029/2007JD008684, 2007.

Zhang, Q., Streets, D. G., Carmichael, G. R., He, K. B., Huo, H., Kannari, A., Klimont, Z., Park, I. S., Reddy, S., Fu, J. S., Chen, D., Duan, L., Lei, Y., Wang, L. T., and Yao, Z. L.: Asian emissions in 2006 for the NASA INTEX-B mission, Atmos. Chem. Phys., 9, 5131-5153, https://doi.org/10.5194/acp-9-5131-2009, 2009.

Zhang, Q., Geng, G., Wang, S., Richter, A., and He, K.: Satellite remote sensing of changes in $\mathrm{NO}_{x}$ emissions over China during 1996-2010, Chinese Sci. Bull., 57, 2857-2864, https://doi.org/10.1007/s11434-012-5015-4, 2012.

Zhang, R. H., Li, Q., and Zhang, R. N.: Meteorological conditions for the persistent severe fog and haze event over eastern China in January 2013, Sci. China Earth Sci., 57, 26-35, https://doi.org/10.1007/s11430-013-4774-3, 2014.

Zhang, R., Wang, G., Guo, S., Zamora, M. L., Ying, Q., Lin, Y., Wang, W., Hu, M., and Wang, Y.: Formation of urban fine particulate matter, Chem. Rev., 115, 3803-3855, https://doi.org/10.1021/acs.chemrev.5b00067, 2015.

Zhang, L., Chen, Y., Zhao, Y., Henze, D. K., Zhu, L., Song, Y., Paulot, F., Liu, X., Pan, Y., Lin, Y., and Huang, B.: Agricultural ammonia emissions in China: reconciling bottom-up and top-down estimates, Atmos. Chem. Phys., 18, 339-355, https://doi.org/10.5194/acp-18-339-2018, 2018.

Zhang, X.-X., Sharratt, B., Liu, L.-Y., Wang, Z.-F., Pan, X.-L., Lei, J.-Q., Wu, S.-X., Huang, S.-Y., Guo, Y.-H., Li, J., Tang, X., Yang, T., Tian, Y., Chen, X.-S., Hao, J.-Q., Zheng, H.-T., Yang, Y.-Y., and Lyu, Y.-L.: East Asian dust storm in May 2017: observations, modelling, and its influence on the Asia-Pacific region, Atmos. Chem. Phys., 18, 8353-8371, https://doi.org/10.5194/acp18-8353-2018, 2018.
Zhao, C., Liu, X., Leung, L. R., Johnson, B., McFarlane, S. A., Gustafson Jr., W. I., Fast, J. D., and Easter, R.: The spatial distribution of mineral dust and its shortwave radiative forcing over North Africa: modeling sensitivities to dust emissions and aerosol size treatments, Atmos. Chem. Phys., 10, 8821-8838, https://doi.org/10.5194/acp-10-8821-2010, 2010.

Zhao, C., Chen, S., Leung, L. R., Qian, Y., Kok, J. F., Zaveri, R. A., and Huang, J.: Uncertainty in modeling dust mass balance and radiative forcing from size parameterization, Atmos. Chem. Phys., 13, 10733-10753, https://doi.org/10.5194/acp-13-107332013, 2013.

Zheng, B., Zhang, Q., Zhang, Y., He, K. B., Wang, K., Zheng, G. J., Duan, F. K., Ma, Y. L., and Kimoto, T.: Heterogeneous chemistry: a mechanism missing in current models to explain secondary inorganic aerosol formation during the January 2013 haze episode in North China, Atmos. Chem. Phys., 15, 2031-2049, https://doi.org/10.5194/acp-15-2031-2015, 2015.

Zheng, G. J., Duan, F. K., Su, H., Ma, Y. L., Cheng, Y., Zheng, B., Zhang, Q., Huang, T., Kimoto, T., Chang, D., Pöschl, U., Cheng, Y. F., and He, K. B.: Exploring the severe winter haze in Beijing: the impact of synoptic weather, regional transport and heterogeneous reactions, Atmos. Chem. Phys., 15, 2969-2983, https://doi.org/10.5194/acp-15-2969-2015, 2015.

Zheng, G., Su, H., Wang, S., Andreae, M. O., Pöschl, U., and Cheng, Y.: Multiphase buffer theory explains contrasts in atmospheric aerosol acidity, Science, 369, 1374-1377, https://doi.org/10.1126/science.aba3719, 2020. 